
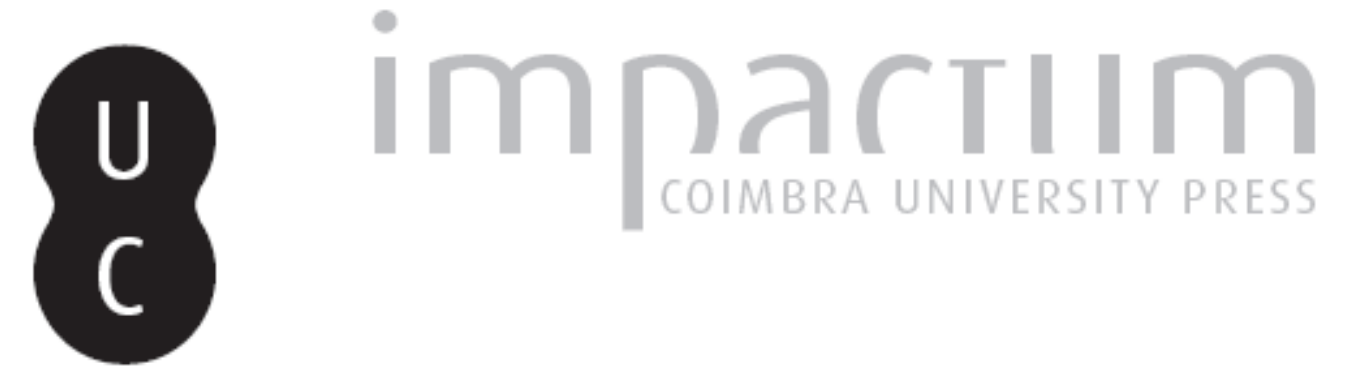

\title{
A extinção da Ordem do Templo em Portugal
}

Autor(es): Gomes, Saul António

Publicado por: Centro de História da Sociedade e da Cultura

URL persistente:

URI:http://hdl.handle.net/10316.2/39478

DOI:

DOI:http://dx.doi.org/10.14195/1645-2259_11_4

Accessed : $\quad$ 26-Apr-2023 09:23:25

A navegação consulta e descarregamento dos títulos inseridos nas Bibliotecas Digitais UC Digitalis, UC Pombalina e UC Impactum, pressupõem a aceitação plena e sem reservas dos Termos e Condições de Uso destas Bibliotecas Digitais, disponíveis em https://digitalis.uc.pt/pt-pt/termos.

Conforme exposto nos referidos Termos e Condições de Uso, o descarregamento de títulos de acesso restrito requer uma licença válida de autorização devendo o utilizador aceder ao(s) documento(s) a partir de um endereço de IP da instituição detentora da supramencionada licença.

Ao utilizador é apenas permitido o descarregamento para uso pessoal, pelo que o emprego do(s) título(s) descarregado(s) para outro fim, designadamente comercial, carece de autorização do respetivo autor ou editor da obra.

Na medida em que todas as obras da UC Digitalis se encontram protegidas pelo Código do Direito de Autor e Direitos Conexos e demais legislação aplicável, toda a cópia, parcial ou total, deste documento, nos casos em que é legalmente admitida, deverá conter ou fazer-se acompanhar por este aviso.

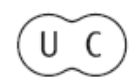




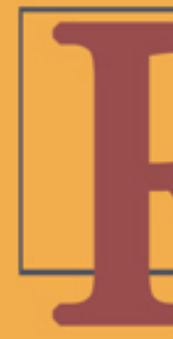

\section{evista de História} da Sociedade e da Cultura

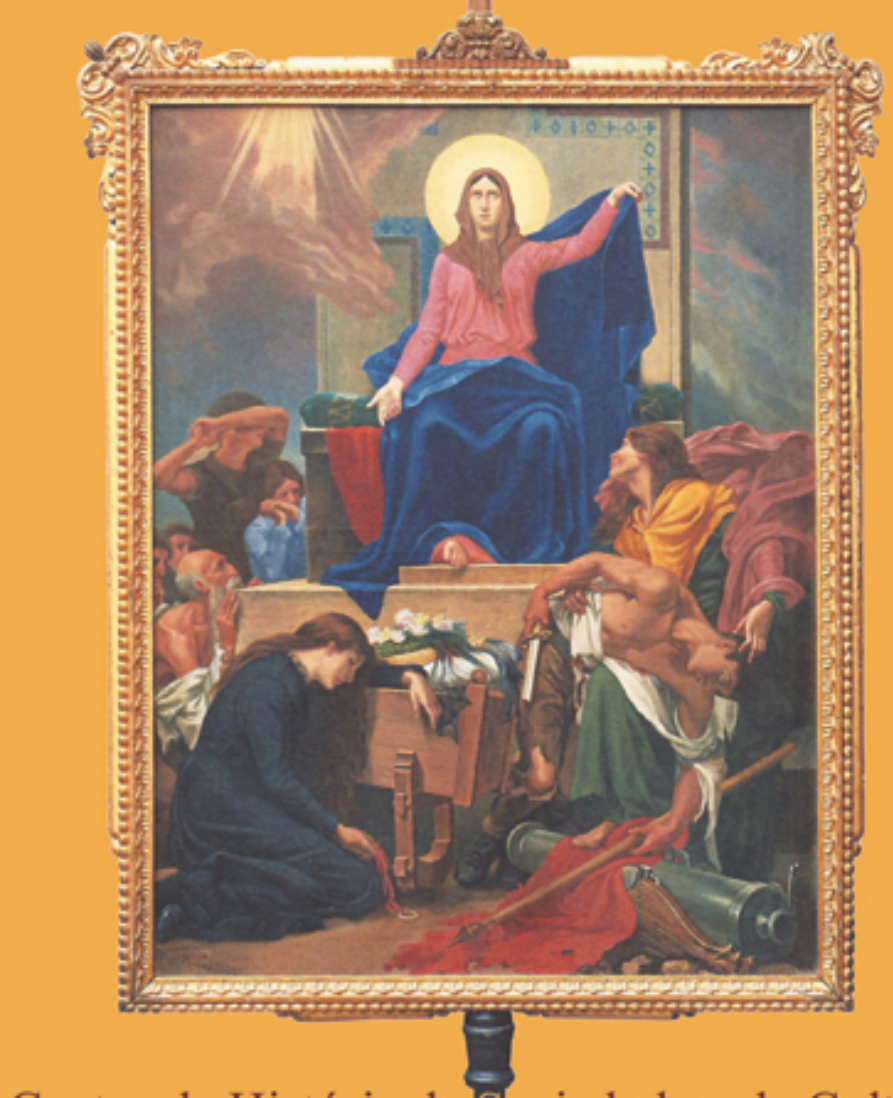

Centro de História da Sociedade e da Cultura Universidade de Coimbra 


\title{
A Extinção da Ordem do Templo em Portugal
}

\author{
Saul António Gomes \\ Universidade de Coimbra e CHSC \\ sagcs@fl.uc.pt
}

Texto recebido em/ Text submitted on: 28/02/2011

Texto aprovado em/ Text approved on: 30/08/2011

\section{Resumo/Abstract:}

Este artigo pretende analisar o problema da extinção da Ordem do Templo em Portugal e da sua sucessão pela Ordem de Cristo. Procede à edição de documentos não publicados integralmente, até ao momento, muito em especial a inquirição levada a cabo por João Pais de Soure, em 1314. Inquirição forense controlada por oficiais ao serviço da Coroa, consequentemente acto documental isento de vício ou de suspeição à partida favorável aos templários, ela permite verificar, mau grado episódios de tensão entre o poder régio e a Ordem, a prevalência estrutural, na memória histórica dos templários portugueses, dos sentimentos de auxílio e de lealdade dos cavaleiros portugueses desta Ordem para com o rei.

This paper intends to examine the extinction of the order of the Knights Templars in Portugal and its succession by the Order of Christ. It edits documents not integrally published until now, specially the inquiry made by João Pais de Soure in 1314. This forensic inquiry controlled by officials serving the Crown is as a consequence a documental instrument free of vice or suspicion in the behalf of the Templars. Thus it enables us to verify, in spite of episodes of tension between the royal power and the Order, the structural prevalence in the historical memory of the portuguese templars of fellow-feelings and loyalty of the Portuguese knights of the Order towards the King.

Palavras chave/Keywords:

Templários; Portugal; D. Dinis; Ordem de Cristo.

Templars; Portugal; D. Dinis; Order of Christ. 
No dia 24 de Junho de 1319, D. Dinis assinou a concessão, à Ordem dos Cavaleiros de Jesus Cristo, das vilas, castelos e lugares de Soure, Pombal, Ega e Redinha, na Estremadura, e de Idanha-a-Velha, Idanha-a-Nova, Salvaterra, Segura, Proença e Rosmaninhal, na Beira. Tais lugares e castelos, referia o monarca, haviam sido ganhos pelo procurador da Coroa, em causa forense antiga, contra o mestre e os freires que haviam sido da Ordem do Templo, no tempo em que durou, citamos as palavras régias, a "demanda e outorvação e dezasocego a dita Ordem tal porque foy desfeyta".

Pretendia D. Dinis, agora, corrigindo uma injustiça levada a cabo contra "Deos e direyto e verdadeyra consciencia", renunciar a tais bens e doá-los à nova Ordem Militar de Cristo. Ordem, entenda-se, "que se agora ha de fazer em reformação da outra sobredita que foy do Templo". A Ordem de Cristo, aprovada pelo papa João XXII, pela bula Ad ea ex quibus, assinada em Avinhão, a 14 de Março de 1319¹, apresentava-se, deste modo, sublinhemo-lo, como "em reformação" da do Templo. A ideia de "reformação" da antiga Ordem, atendendo à lexicografia da carta régia que analisamos, significa, de algum modo, a consciência política dionisina de que a Ordem de Cristo se incorporava na herança da do Templo e herdava-lhe, consequente e legitimamente, todos os bens, ainda nas palavras do soberano, "tambem temporaes como espirituães".

Todas as sentenças dadas em prejuízo do Templo ficavam, assim, derrogadas e a "posse e propriedade", que el-rei houvera, por sentenças que se reconheciam, em 1319, juridicamente inválidas por vício processual e negação ou inviabilidade de audiência à parte acusada, a dos cavaleiros de Salomão, dos antigos lugares e castelos templários, devolvida aos freires de Cristo $^{2}$.

Mas é conveniente afirmar que, se no documento real antes citado, se fala de "reformação", na bula do papa João XXII, Ad ea ex quibus, também referida, o vocabulário expresso, para enunciar a Ordem de Cristo, é o de "noui ordinis" ou "nouam Christi miliciam", então estrategicamente

1 Monumenta Henricina, [Org. Manuel Lopes de Almeida, Idalino Ferreira da Costa Brochado e António Joaquim Dias Dinis]. Coimbra: Comissão Executiva das Comemorações do V Centenário da Morte do Infante D. Henrique, 1960, Vol. 1, Doc. 61, pp. 97-110.

2 Direcção Geral de Arquivos / Torre do Tombo (Lisboa) (doravante citada por TT) Tombos das Comendas, $\mathrm{N}^{\circ}$ 409, fls. 7-8. 
estabelecida na Diocese de Silves, fronteira mais vizinha aos inimigos da Fé cristã, ficando encabeçada em Castro Marim³ ${ }^{3}$. A versão portuguesa dessa bula, dada por Domingos Eanes, tabelião de Santarém, em pública-forma de 11 de Maio de 1320, traduz literal e significativamente o conceito em causa por "noua caualaria"4.

A 18 de Novembro de 1319, em Lisboa, a Cúria real testemunhava a "ordenação da caualaria de Jhesu Christo", assim se oficializando "a noua ordenaçom da casa da caualaria de Jhesu Christo que foy logo canonicamente celebrada per o dicto senhor rey". Dois dias depois, o novo mestre da Ordem, Fr. Gil Martins, com o convento da Milícia, passava declaração de quitação, ao monarca, dos bens que a Cora recebera da extinta Ordem do Templo, agora transferidos para a Ordem de Cristo ${ }^{6}$. A 11 de Junho de 1321, na ordenação da Cavalaria de Jesus Cristo, promulgada pelo seu "primeyro meestre", regista-se que era Ordem "feyta nouamente". As expressões "nova" e "novamente", naquele tempo, correspondem, como se sabe, à ideia de algo que se concretiza pela primeira vez, ou seja, de acto fundacional de raiz.

Mas esta afirmação oficial da "novidade" da Ordem de Cristo, procuraria, sobremodo, demarcar a sua originalidade face à desaparecida Ordem do Templo, mais, como se anotou, como discurso jurídico, do que como entidade estabelecida ex nihilo. O conceito de "reformação", também usado na documentação, todavia, não deixa de ser significativo das concepções plurais que, em tal matéria, circulavam entre os oficiais e redactores da chancelaria régia à época.

Quando, no dia 13 de Outubro de 1307, Filipe, o Belo, rei de França, deu ordem de prisão dos cavaleiros templários existentes no seu reino, assim despoletando o complexo processo, que se estenderá à Península Ibérica e demais países europeus nos quais se registava a presença dos

\footnotetext{
3 Monumenta Henricina, Vol. I, Docs. 61 e 63, p. 106 e 119.

4 Monumenta Henricina, Vol. I, Doc. 62, p. 110-119: 112.

5 Monumenta Henricina, Vol. I, Foc. 67, p. 126-128: 127.

6 Monumenta Henricina, Vol. I, Doc. 68, p. 129-131.

7 Monumenta Henricina, Vol. I, Doc. 73, p. 142-150: 143.
} 
cavaleiros templários ${ }^{8}$, e que culminará na supressão da Ordem, decretada no Concílio de Vienne, de $1312^{9}$, governava o mestrado português templário, desde 1295, D. Vasco Fernandes ${ }^{10}$.

Seria este mestre, no seguimento das tentativas feitas para o estabelecimento de um catálogo dos prelados da Ordem em Portugal, o $24^{\circ}$ governador templário em terras de Portugal ${ }^{11}$. Cumpria aos mestres governar

8 JOSSERAND, Philippe - Église et pouvoir dans la Péninsule Ibérique. Les Ordres Militaires dans de Rouyaume de Castille (1252-1369). Madrid: Casa de Velázquez, 2004, p. 50-60 et passim.

9 Vd. GODES, Jesús Mestre - Os Templários. Alvorada e crepúsculo dos cavaleiros. Lisboa,: Pergaminho, 2001, p. 159 e seguintes; DEMURGER, Alain - Jacques de Molay. Le crépuscule des Templiers. Paris: Payot \& Rivage, 2002; IDEM - Les Templiers. Une chevalerie chrétienne au Moyen Âge. Paris: Le Seuil, 2005.

${ }^{10}$ FERNANDES, Maria Cristina Ribeiro de Sousa - A Ordem do Templo em Portugal (Das origens à extinção), [Dissertação de Doutoramento, policopiada]. Porto: Faculdade de Letras da Universidade do Porto, 2009, p. 153.

${ }^{11} \mathrm{O}$ elenco dos mestres da Ordem do Templo em território português varia de autor para autor. Fr. Bernardo da Costa conta 33 mestres, neles integrando os mestres dos "Três Reinos" (Historia da Militar Ordem de Nosso Senhor Jesus Christo dedicada a El-Rey D. Joseph I, Coimbra, Oficina de Pedro Ginioux, 1771, p. 119). Fr. António Brandão apresenta uma lista de 11 mestres (vd. CAPÊLO, José Manuel - Portugal Templário. Relação e sucessão dos seus Mestres (1124-1314). Lisboa: Aríon Publicações, 2003, p. 225). Fr. José de Brito elenca 24 mestres (vd. PARASHI, André Jean - História dos Templários em Portugal. A fundação e os Mestres da Ordem. Ericeira: 1992, p. 85-93). Fr. Lucas de Santa Catarina aponta 22 mestres ("Catalogo dos Mestres da Ordem do Templo Portuguezes, que tiverão e exercitarão este titulo e cargo nesta Coroa Portugueza, e em outras de Hespanha”, Collecçam dos documentos e memorias da Academia Real da Historia Portugueza, que neste anno de 1722 se compuzerão..., Lisboa, Academia Real da Historia, 1722). Diferente número dos anteriores é exposto por Alexandre Ferreira (Supplemento historico ou memorias e noticias da celebre Ordem dos Templarios, para a historia da admiravel Ordem de Nosso Senhor Jesu Christo, 2 vols., Lisboa: Oficina de J. A. da Sylva, 1735; FERREIRA Alexandre e GOMES, Manuel, Historia das Ordens Militares que houve no Reyno de Portugal, Lisboa, Academia Real da Historia, 1735 (reimpressão, Lisboa, 1998)). Fr. Joaquim de Santa Rosa de Viterbo enuncia 28 mestres, (Elucidário das Palavras, Termos e Frases que em Portugal antigamente se usaram... (Edição crítica por Mário Fiúza, Vol. II. Porto-Lisboa: Livraria Civilização, 1966, s. v. “Tempreiros”, p. 582-602). Vieira Guimarães lista 27 nomes (Ordem de Christo, Lisboa: Imprensa Nacional de Lisboa, 1936, p. 441), no que foi seguido por François Gutton (Le Chevalerie Militaire au Portugal (L'Ordre du Temple, l'Ordre du Christ, l'Ordre d'Avis, l'Ordre de Santiago). Paris: 1981, p. 25). Mário Simões Dias arrola 32 sucessões (Os Templários em Portugal. Coimbra, 1999, p. 67) no que é seguido por J. Pinharanda Gomes (A Regra Primitiva dos Cavaleiros Templários. Lisboa: Hugin, 1999, p. 9). José M. Valente 19 mestrados (Soldiers and settlers: the knights Templar in Portugal, 1128-1319, (Dissertação de Doutoramento policopiada), Santa Barbara, University of California, 2002). José Manuel Capêlo fixa esse número em 28 mestres (Op. cit., pp. 225-237: 236-237). Finalmente, na sua dissertação de doutoramento, Maria Cristina Fernandes estabelece um 
e gerir os interesses da Ordem em Portugal ou, em certos momentos, no conjunto dos reinos de Portugal, de Castela e de Leão. Nas suas mãos, ainda, faziam voto de obediência, de castidade e de pobreza todos os novos freires e das suas mãos recebiam a investidura ${ }^{12}$. Enquanto responsáveis pelos mestrados provinciais, os mestres mantinham activo o corpo militar da Ordem, constituído por cavaleiros e servidores ("sergentes"), mas também arqueiros e peões, saídos dos territórios onde os templários se haviam estabelecido ou mesmo recrutado como mercenários. Poderia haver cavaleiros associados temporariamente ou ad terminum à Ordem em razão de objectivos militares ou outros. A Ordem contava, ainda, com fratres coniugati. Um lugar específico dentro dos conventos da Ordem era ocupado pelos capelães ou clérigos. Muitos benfeitores, originários das aristocracias urbanas e da pequena ou mesmo grande nobreza, por seu turno, adquiriram o estatuto de confratres e participavam dos benefícios espirituais e canónicos que a Igreja havia atribuído à Milícia do Templo de Salomão. Numerosos servidores e dependentes, para além de escravos ou cativos oriundos das presas de guerra, finalmente, garantiam a mão-de-obra indispensável à exploração dos extensos patrimónios dominiais da $\mathrm{Ordem}^{13}$.

Também a administração senhorial, dos territórios da Ordem, introduziu nela outras hierarquias de direcção e de exercício de poderes, confluentes com a organização antedita, às quais cumpria gerir as províncias, as bailias e as comendas. Na gestão destas unidades eram colocados homens da confiança da hierarquia desta Cavalaria, bem assim dos quadros governantes de cada reino ou senhorio, com a finalidade de ocuparem alcaidarias de castelos e de vilas, a que se juntavam, ainda, procuradores, para além de

rol de 17 nomes (A Ordem do Templo em Portugal (Das origens à extinção), [Dissertação de Doutoramento, policopiada], cit., p. 142-146. (Esta Autora arrola, ainda, sete mestres nos três reinos de Portugal, Castela e Leão).

${ }^{12}$ Vd. GOMES, J. Pinharanda - A Regra Primitiva ..., cit., p. 27-34.

${ }^{13}$ Sobre as hierarquias próprias da Ordem do Templo, vejam-se as sínteses apresentadas por DEMURGER, Alain - "Ordre du Temple", Prier et Combattre. Dictionnaire européen des ordres militaires au Moyen Âge, cit., p. 896-902; BARBER, M. C. - The social context of the Templars. Transactions of the Royal Historical Society, Fifth Series, Vol. 34 (1984) 27-46; GERRARD, Christopher - Opposing Identity: Muslims, Christians and the Military Orders in Rural Aragon. Medieval Archeology, Vol. 43 (2000) 143-160; CAPÊLO, José Manuel - Op. cit., p. 259-265. 
corpos de oficiais mais especializados como sucedia, por mero exemplo, com os responsáveis pelas chancelarias mestrais e os escrivães seus amanuenses ${ }^{14}$.

Em Portugal, onde os templários começam por receber o lugar de Soure em 1128, e a que somaram, pouco depois, outras terras onde levantaram castelos ou renovaram as fortalezas preexistentes ${ }^{15}$, já na década de 1170 se referenciam as comendas da Ordem, significando isso que esta figura institucional serviu as lógicas de povoamento e de apropriação dos territórios que lhe foram doados e sujeitos. O sistema de comenda cedo se atesta, de facto, vindo referido, por exemplo, no foral concedido pela Ordem a Pombal, em $1176^{16}$, conhecendo-se, também, a existência de comendadores em Tomar, por 1177-1179 ${ }^{17}$, e em Almourol, no ano de $1188^{18}$.

$\mathrm{O}$ estado de guerra contra o infiel, sobretudo na Palestina, exigia às bailias e comendas templárias um enorme esforço de participação em homens, em armas e em financiamento, sem os quais seria vã a defesa da Terra Santa e a segurança dos cristãos que a procuravam por motivações religiosas ou outras. Tenhamos presente, ainda, que este enorme esforço de guerra encontrara, na Península Ibérica, uma segunda frente ${ }^{19}$, nela

${ }^{14}$ GOMES, S. A. - Observações em torno das Chancelarias das Ordens Militares em Portugal, na Idade Média. As Ordens Militares e as Ordens de Cavalaria na Construção do Mundo Ocidental - Actas do IV Encontro sobre Ordens Militares. Lisboa: Edições Colibri / Câmara Municipal de Palmela, 2005, p. 111-167; IDEM - Observações em torno da chancelaria da Ordem do Templo em Portugal. As Ordens Militares e as Ordens de Cavalaria entre o Ocidente e o Oriente. Actas do V Encontro sobre Ordens Militares (Coord. FERNANDES, Isabel Cristina F.). Palmela, Município de Palmela - GESOS, 2009, p. 121-139.

${ }^{15}$ Vd. BARROCA, Mário - A Ordem do Templo e a arquitectura militar portuguesa do século XII. Portugália, Nova Série, 17-18 (1996-1997) 171-209; IDEM - "Soure (Portugal, Beira)", in Prier et combattre. Dictionnaire..., cit., p. 884.

${ }^{16}$ COSTA, Fr. Bernardo da - Historia da Militar Ordem..., p. 204-212; Portugaliae Monumenta Historica - Leges et consuetudines (Org. Alexandre Herculano). Vol. I, Lisboa: Academia das Ciências de Lisboa, 1856, p. 404-405. Vd., ALVES, Gracilda - Poder e sociedade na região de Pombal, Soure, Ega e Redinha (1385-1481). (Tese de Doutorado em História Medieval). Niterói, Universidade Federal Fluminense, 2001); FERNANDES, Fabiano - Poder religioso e centralização régia nas vilas de Ega, Soure, Redinha e Pombal. 1248-1348. Atas da IV Semana de Estudos Medievais, Rio de Janeiro, 2001.

${ }^{17}$ CONDE, Manuel Sílvio Alves - Tomar Medieval. O espaço e os homens. Cascais: Patrimonia, 1996, p. 242.

${ }^{18}$ FERNANDES, Maria Cristina - Op. cit., p. 154-159.

${ }^{19} \mathrm{Vd}$., sobre este problema, a síntese mais recente devida a JOSSERAND, Philippe Entre dos frentes: aproximación a las empresas militares de los Templarios del occidente 
se notabilizando os mestres e cavaleiros portugueses sendo de nomear, entre eles, o conhecido D. Gualdim Pais ${ }^{20}$. Depois da cidade de Jerusalém, em 1187, os templários elegeram Acre como centro de comando da Ordem, a qual, cumpre recordar, perderão tragicamente em $1291^{21}$.

Desconhecemos, com precisão, qual a idade que tinha o Mestre D. Vasco Fernandes no momento em que a Ordem foi atingida pelos ventos da perseguição que levaram à sua extinção. O mestre português deveria ter, todavia, idade respeitável, uma vez que deveremos admitir que só depois de um generoso ou mesmo longo percurso como freire e cavaleiro, se viu elevado à cadeira mestral da Ordem em Portugal. Mas tanto D. Vasco Fernandes, como a generalidade dos seus confreires, deveria representar uma geração cuja mancebia e entrada na vida adulta, cremos, se teria passado ainda no reinado de D. Afonso III.

Representavam, ele e os seus cavaleiros, assim sendo, uma geração já de pós-reconquista do reino do Algarve, concluída, como se sabe, em 1249. Certo é que, mesmo depois desta data, Portugal não pôde sossegar inteiramente, em matéria de alerta militar contra mouros ou, sobremodo, de defesa das fronteiras entretanto estabelecidas com os reinos vizinhos de Castela-Leão e também da área granadina, permanecendo reais as ameaças de corso ou pirataria muçulmana nas costas algarvias e mesmo no litoral atlântico português. Motivações que continuariam a reconhecer a utilidade

peninsular (siglos XII-XIV). Hacedores de Frontera. Estudios sobre el contexto social de la Frontera en la España medieval (Dir. Manuel Alejandre Rodríguez de la Peña). Madrid, 2009, p. 179-201.

${ }^{20}$ Vd. ALMEIDA, Fortunato de - História da Igreja em Portugal (Nova edição preparada e dirigida por Damião Peres), Vol. I. Porto: Portucalense Editora, 1967, p. 146-148; BARROS, Henrique da Gama - História da Administração Pública em Portugal nos Séculos XII a XV ( $2^{a}$ edição dirigida por Torquato de Sousa Soares), Tomo II. Lisboa: Livraria Sá da Costa, 1945, p. 292-300 e 322-321; COSTA, António Domingues de Sousa - Introdução. Monumenta Portugaliae Vaticana. Vol. II. Súplicas dos pontificados dos papas de Avinhão Clemente VII e Bento XIII e do papa de Roma Bonifácio IX. Braga, 1970, p. VII-LVI; FONSECA, Luís Adão da - Ordens Militares. Dicionário de História Religiosa de Portugal (Dir. Carlos Moreira Azevedo), Vol. J-P. Lisboa: Círculo de Leitores, 2001, p. 334-345; VALENTE, José M. - Soldiers and settlers: the knights Templar in Portugal, 1128-1319, (Dissertação de Doutoramento policopiada). Santa Barbara: University of California, 2002.

${ }^{21}$ DEMURGER, Alain - Vie et mort de l'Ordre du Temple. Paris: Seuil, 1989; IDEM Templiers. Dictionnaire Encyclopédique du Moyen Âge (Dir. André Vauchez), vol. 2. Paris: Cerf, 1997, p. 1487-1488; GODES, Jesús Mestre - Os Templários..., p. 74-80; PERNOUD, Régine - Os Templários. Mem Martins: Publicações Europa-América, 1982. 
estratégica dos cavaleiros templários, como das milícias de outros institutos religioso-militares, em território nacional.

Deveremos ter presente, por outro lado, que, muito embora desde os primórdios da presença templária em Portugal, os seus cavaleiros aqui estantes se comprometessem sobremodo com a guerra, ao serviço do soberano dos portugueses, contra os mouros, mais do que na Terra Santa, e que a entrada e saída de mestres e de cavaleiros templários para irem "além-mar", fosse o mais possível controlada pelo poder régio, isso não significa, naturalmente, que não se tenham verificado deslocações de cavaleiros templários portugueses para prestarem serviço na guerra cruzadística no Médio Oriente ou noutros lugares oportunos.

Conhecemos assaz mal, contudo, para o caso português, a história endógena do que foi a vida templária nesses tempos medievais tão distantes. Não há dúvida de que os Cavaleiros do Templo de Salomão edificaram castelos, vilas e lugares de grande arrojo monumental e urbanístico. Nas terras que senhorearam deixaram marcas profundas da sua cultura tanto material quanto imaterial que, ainda agora, perduram. Mas esse majestoso património artístico, arquitectónico, urbanístico e paisagístico, em que Portugal é felizmente um caso maior no contexto europeu, não nos chega acompanhado das necessárias fontes escritas que nos possam elucidar dessa história interior da Ordem, como acabo de referir ${ }^{22}$.

É certo que, em matéria documental, os castelos templários, especialmente aqueles que se afirmaram como pólos mais centrípetos da administração da Ordem em Portugal, tiveram arquivos seguros e conheceram contabilidades, inscritas em livros de registos diversos. Não faz sentido, nem boa verdade, que os templários, mormente os portugueses, tenham escrito pouco ou deixado magros arquivos, bem pelo contrário, mas também deveremos considerar que, em determinadas matérias, prevalecia, como cultura institucional da

${ }^{22}$ Posto que, nalguns momentos, sobretudo com Mestre D. Gualdim Pais, a edificação de um novo castelo fosse acompanhada pela exposição pública e solene de grandes lápides epigráficas comemorativas do acontecimento. Vd. BARROCA, Mário-A Ordem do Templo e a arquitectura militar portuguesa do século XII. Portugália, Nova Série, 17-18 (1996-1997), p. 171-209: IDEM - Epigrafia Medieval Portuguesa (862-1422). Vol. II. Corpus epigráfico medieval português, Tomo I. Porto: Fundação Calouste Gulbenkian e Fundação para a Ciência e a Tecnologia, 2000, p. 249-254, 271-276, 348-369. 
Ordem, o segredo, atitude que terá desincentivado a escrituração de certas decisões ou aconselhado a eliminação de actos escritos comprometedores.

Foi no maior segredo, por exemplo, que, em 1314, alguns inquiridores régios andaram junto de antigas vilas templárias, nomeando-se, especialmente, Soure, Castelo Branco, Montalvão, Nisa e Tomar, levantando informação acerca da história, da natureza dos bens templários, da dependência dos seus cavaleiros face aos mestres da Ordem e aos reis de Portugal, do exercício da autoridade e poder pelos mesmos, da aceitação, em Portugal, de novos cavaleiros, da obediência, sujeição e vassalidade dos freires ao rei e da sua missão privilegiada, afirmada por juramento solene feito nas mãos do monarca, de obedecerem, defenderem e ampararem quer a real pessoa quer toda a sua família ${ }^{23}$.

E, nestas inquirições, muitos falaram, sobretudo vizinhos laicos moradores nos concelhos de senhorio ex-templário, emergindo, no rol dos depoentes, clérigos e criados que foram da Ordem, mesmo, posto que mais discretamente, alguns que haviam sido freires professos. Um deles, em Castelo Branco, recusar-se-ia inclusive a prestar qualquer declaração, salvo se visse assinado régio que a isso o mandasse, porque só obedeceria a seu rei: "Gil Fernandez Barreto vistos todolos artigoos disse que el era criado e mercee del rey e quando visse sa carta ou seu recado certo que el diria o que sabia <e que sabia> mays ca o que era conteudo nos artigos. E que non avia homem no reyno que ende tanto soubesse que fosse a seu serviço." ${ }^{24}$

Deste depoimento, como de outros, pelo zelo dos oficiais régios que levaram o auto da sua inquirição ao arquivo da Torre do Tombo, onde agora o achamos, posto que fragmento incompleto, houve o maior cuidado e secretismo, concluindo, aliás, o relator do mesmo inquérito com as palavras que passamos a citar: "E leudos estes artigoos e cada huum specificadamente sobre sy amte cada huã das pessõas sobredictas apartadamente e em gram

${ }^{23}$ TT - Gaveta VII, M 2 , Doc. 4 e M $^{\circ}$ 18, Doc. 2; B) Leitura Nova: Livro de Mestrados, fls. $143 \mathrm{v}^{\mathrm{o}}-150$. Ref $^{\mathrm{a}}$ : RIBEIRO, João Pedro - Memorias para a Historia das Inquirições dos primeiros reinados de Portugal. Lisboa: Impressão Regia, 1815, p. 117.

${ }^{24} \mathrm{TT}$ - Leitura Nova: Livro de Mestrados, fl. $148 \mathrm{v}^{\mathrm{o}}$. 
segredo achamos que os dictos artigoos se podem bem provar per eles salvo dous artigos." 25

Governava Portugal, como bem sabemos, nesses distantes anos dentre 1306 e 1312, D. Dinis, sentando-se a seu lado, no trono, a rainha D. Isabel, oriunda da casa real aragonesa ${ }^{26}$. Portugal viveu, neste reinado, um período de franca prosperidade. D. Dinis revelou-se um rei, sob muitos aspectos, reformador, acarinhando a emergência de novas dinâmicas económicas e sociais, traduzidas, por exemplo, na sua política para com os concelhos e senhores, laicos ou eclesiásticos, para com o comércio interno e externo, para com o estabelecimento de novas póvoas, sobretudo no litoral atlântico, bem como para uma política de reordenação das paisagens naturais fornecedoras de recursos e de matérias-primas, para investimento, que impulsionou, em matéria de formação de quadros administrativos superiores, sobretudo na área do Direito, e, finalmente, pela afirmação internacional de Portugal como reino com um efectivo peso na política ibérica e europeia desse tempo ${ }^{27}$.

Dos tempos de D. Afonso III, a Ordem colhera tanto a satisfação de promessas de respeito pelos seus privilégios antigos, quanto, já na década final do reinado de 1270, alguma firme reivindicação do monarca em matéria de verificação dos seus direitos sobre terras como Mogadouro e Penas Róias ou em relação aos termos municipais de Montemor-o-Velho, Soure e Pombal $^{28}$. Acontecimentos de tensão entre poder real e poderes eclesiais, como sabemos, repetiram-se frequentemente nos tempos medievais em Portugal. Todavia, como passaremos a expor, as relações da Ordem do Templo com o novo rei, D. Dinis, pautar-se-ão mais pela concórdia e até, nos anos de fogo de 1307-1312, pela protecção do monarca aos seus membros, do que por uma situação de conflito permanente.

${ }^{25}$ Idem, ibidem, fls. $149 \mathrm{v}^{\mathrm{o}}-150$.

${ }^{26}$ Vd. COELHO, Maria Helena da Cruz - Esboço sobre a vida e obra da Rainha Santa Isabel. Monumentos, 18, Lisboa (2003) 25-33.

${ }^{27}$ Para um conhecimento mais aprofundado da vida e obra deste monarca, leia-se, por todos, PIZARRO, José Augusto de Sotto Mayor - D. Dinis. Lisboa: Círculo de Leitores, 2005. Nesta obra, nas páginas 165-166, aborda-se o problema das relações entre o Rei, a Ordem do Templo e o estabelecimento da Ordem de Cristo.

${ }^{28}$ Chancelaria de D. Afonso III (Ed. Leontina Ventura e António Resende de Oliveira), Livro I - Vol. 2. Coimbra: Imprensa da Universidade, 2006, docs. 526, 640, 687 e 705. 
Desde que D. Dinis inaugurou o seu reinado, em 1279, com 18 anos de idade, sentaram-se no sólio mestral do Templo seis mestres. D. Beltrão de Valverde governava o mestrado português ainda em 1280, ano em que foi substituído por D. João Scriptor. Em 1283, no entanto, já o mestre, cremos, seria outro, D. João Fernandes, que geriria os destinos templários lusitanos até 1288. Sucedeu-lhe D. Afonso Gomes, por breves anos, pois que terminou o seu mandato em 1291, ano em que se deu obediência a D. Lourenço Martins ${ }^{29}$, que, por sua vez, deu lugar, em 1293, ao mencionado D. Vasco Fernandes, do qual sabemos que se mantinha à frente da Ordem, em território nacional em 1306 e, ainda, tudo o leva a admitir, no momento da extinção da Ordem, em 1312. D. Vasco Fernandes foi, assim, o último mestre dos Templários em Portugal ${ }^{30}$.

Se excluirmos D. Beltrão de Valverde, cujo governo coincide apenas num ano com o reinado dionisino, teremos, para sete mestres, governos médios de quatro anos. Naturalmente, este número é apenas um indicador, tanto mais que o último mestre, D. Vasco Fernandes, governou entre treze para catorze anos. Mas é uma excepção. Por renúncia, por morte, por intervenção régia que sabemos ser uma prática corrente nesta matéria, ou por outros motivos menos conhecidos, os mestres que imediatamente o antecederam geriram os destinos templários em Portugal, todos eles, por períodos de tempo muito curtos.

Significará, isso, instabilidade interna na Milícia, uma vez que, para os cânones governativos medievais, deveremos associar à ideia de longevidade da governação a de estabilidade política e institucional? Significará, tão simplesmente, que tais mestres o foram em provecta idade, suficiente para não lhes permitir permanências maiores na cadeira mestral? Outras razões eventualmente relacionadas com a mobilidade militar desses cavaleiros?

${ }^{29}$ D. Lourenço Martins viria a falecer apenas em 1308, conforme o antigo epitáfio do seu túmulo, outrora existente na Capela de Santa Maria dos Olivais de Tomar: "Aqui jaz D. Lourenço Martins que foi mestre do Templo do Reyno de Portugal e passou em dia de Mayo da Era 1346." (Citado por BRANDÃO, Fr. Francisco - Monarquia Lusitana, Parte Sexta (nova edição fac-similada com introdução de A. da Silva Rego. Lisboa: Imprensa Nacional - Casa da Moeda, 1980) p. 111. (Doravante citado por Monarquia Lusitana, VI).

${ }^{30}$ COSTA, Fr. Bernardo da - Op. cit.,, p. 119. 
Poderemos considerar que, no seu longo reinado, o relacionamento de D. Dinis com os cavaleiros templários portugueses atravessou grosso modo três fases. A primeira respeita ao período anterior às perseguições à Ordem, desencadeadas em 1306-1307; a segunda fase importa aos anos do "desfazimento" (1307-1312/1314), para usar uma palavra do vocabulário dionisino neste contexto; a terceira e última fase, que vai até ao fim do principado dionisino, coincidindo com os anos dentre 1314/1318 e 1325, importa ao relançamento das funções, e até, em boa medida, do espírito, da antiga Milícia, reformada e renovada com a designação de Ordem de Cristo, superiormente aprovada pela bula Ad ea ex quibus, do papa João XXII, promulgada, em Avinhão, no dia14 de Março de $1319^{31}$.

Nestes três períodos, as relações entre a Coroa de Portugal e os cavaleiros do Templo aqui residentes pautaram-se por uma atitude dominante de lealdade dos freires milicianos para com o monarca e de protecção deste para com eles. Há que reconhecer que, desde logo, D. Dinis encontra uma cavalaria templária maioritariamente portuguesa, ou seja, e com base nos indícios documentais que recolhemos, uma Ordem que, no seu flanco lusitano, se caracterizava, ao nível dos seus elementos, pela prevalência de uma assumida identidade nacional (o que contrasta, assinale-se, com os

${ }^{31}$ Monumenta Henricina, Vol. I, Doc. 61. Ainda que alguns meses mais tarde, também a Coroa de Aragão seguiu uma solução próxima da lusitana, estabelecendo a Ordem de Nossa Senhora de Montesa, nas imediações de Valencia, a qual foi aprovada por João XXII em 22 de Julho de 1319. (Vd. Monarquia Lusitana, VI, p. [57]). Cf. Ayala Martinez, Carlos - Las Órdenes Militares y los procesos de afirmación monárquica en Castilla y Portugal (1250-1350). As relações de fronteira no século de Alcanices. Actas das IV Jornadas Luso-Espanholas de História Medieval, Vol. 2. Porto, 1998, p. 1279-1312. Para a história da Ordem de Cristo em Portugal, veja-se: GUIMARÃES, J. Vieira da Silva - A Ordem de Christo, Lisboa, Imprensa Nacional, 1936; COCHERIL, Maur - Routier des Abbayes Cisterciennes du Portugal. Paris: Fundação Calouste Gulbenkian - Centro Cultural Português, 1978, p. 431-436; SOUSA, João Silva - A Casa Senhorial do Infante D. Henrique. Lisboa: Livros Horizonte, 1991, p. 136-163; SILVA, Isabel Luísa Morgado de Sousa e - A Ordem de Cristo durante o Mestrado de D. Lopo Dias de Sousa (1373?-1417). Militarium Ordinum Analecta. 1. As Ordens Militares no Reinado de D. João I. Porto: Fundação Eng. António de Almeida, 1997, p. 9-128; IDEM - A Ordem de Cristo (1417-1521). Militarium Ordinum Analecta. 6. A Ordem de Cristo (1417-1521). Porto: Fundação Eng ${ }^{\circ}$ António de Almeida, 2002, p. 5-503; VASCONCELOS, António Maria Falcão Pestana de Vasconcelos - A Ordem Militar de Cristo na Baixa Idade Média. Espiritualidade, Normativa e Prática. Militarium Ordinum Analecta. 2. As Ordens de Cristo e de Santiago no início da Época Moderna: a normativa. Porto, Fundação Eng ${ }^{\circ}$ António de Almeida, 1998, p. 5-97. 
tempos fundacionais da Ordem em Portugal) e por uma relação institucional do mestre e cavaleiros portugueses com o rei de íntima dependência e vassalagem.

De acordo com as declarações das testemunhas ouvidas, na citada inquirição de 1314, acerca da natureza dos bens dos templários, em Portugal, da dependência destes face à Coroa e das pessoas dos cavaleiros, do seu poder e das suas relações com a autoridade régia, ordenada em 25 artigos, detectamos como características luso-templárias predominantes os seguintes factores $^{32}$ : a) uma consciência histórica informada acerca do princípio do estabelecimento da Ordem em Portugal e do contrato então estabelecido com os Condes D. Henrique e D. Teresa, bem como com seu filho, o rei D. Afonso, pelo qual os cavaleiros se comprometiam essencialmente a fazer guerra aos mouros no palco da reconquista cristã hispânica e a colaborar na "guarda" de Portugal e no serviço ao rei ${ }^{33}$; b) que os reis portugueses sempre entregaram aos templários muitos lugares, vilas e castelos, concedendo-lhes o direito de os "lavrarem e melhorarem" e de receberem as suas rendas e frutos, contra a prestação de auxílio permanente na guerra contra os mouros, na defesa do reino, mas sem estarem autorizados a "levar nenhuã cousa ao maestre daalem mar senom per lecença del rey de Portugal, ca diziam os reys de Portugal que queriam que as dictas rendas e averes se despendessem na sa terra"; c) que os reis de Portugal filhavam para si, muitas vezes, as vilas e castelos e lugares dos templários, usando-os para dotação de membros da família real, metendo neles alcaides seus e recebendo as respectivas rendas, sem nunca os cavaleiros terem posto em causa essa prática ${ }^{34}$; d) que as despesas da colaboração militar dos templários, "com cavalos e com armas e com todolos seus" no defendimento de Portugal, em guerras e frontarias, e onde quer que "mester fosse" e como "aprouguesse" aos monarcas, sempre foram assumidas pelo Mestrado, nada recebendo este, a título de ressarcimento, por parte da Coroa; e) que os mestres e cavaleiros em Portugal "viviam e faziam menagem e juramento aos reys de Portugal

${ }^{32}$ Gaveta VII, M 2 , Doc. 4 e $\mathrm{M}^{\mathrm{o}}$ 18, Doc. 2; B) Leitura Nova: Livro de Mestrados, fls. $143 \mathrm{v}^{\circ}-150$. (Apêndice documental deste artigo, doc. 1). Também resumidos parcialmente por Fr. Francisco Brandão, Monarquia Lusitana, Vol. VI, p. 215-218.

${ }^{33} \mathrm{Vd}$. Apêndice, doc. 1.

${ }^{34} \mathrm{Vd}$. Apêndice, doc. 1. 
polas cousas que tinham", que nenhum mestre entrava no reino ou dele saía para o "além-mar" senão por mandado do rei e que "non seeria maestre senon per sa vontade"; f) que sempre haviam provido "aos dictos reys de Portugal e a seus filhos e a sa familia e a toda sa gente avondadamente e honrradamente de cevada e de viandas e de todas outras cousas que ouvesse mester cada [vez] que passassem ou acaecessem" nos castelos, vilas e propriedades comendas dos templários; g) que o grão-mestre templário em Portugal não recebia novos freires, salvo portugueses, e que ninguém se faria freire, em Portugal, contra a vontade do rei $^{35}$; h) que os cabidos ou capítulos da Ordem para se darem as bailias e tenças eram feitos sempre com o assentimento régios e que o monarca enviava sempre para assistirem a essas assembleias "hum home boom ou dous de sa casa pera veer como se as bailias davam e pera os non leixar pelejar"; i) que os templários e toda a sua família e toda a sua gente eram da jurisdição e do senhorio dos reis de Portugal, tanto em feitos cíveis como crimes, sendo que as apelações das causas subiam sempre à corte régia; j) que os povos moradores nos concelhos, vilas, castelos e lugares da Ordem, em Portugal, não eram obrigados a ir a fossado ou a satisfazer anúduvas a não ser por carta e por mandado del-rei "cujos concelhos eram"36.

D. Dinis relacionava-se, como vemos, com uma Ordem Militar que, na sua vertente portuguesa, se mostrava bastante obediente, fiel e prestável ao monarca e às suas políticas. Não estranha, assim, que D. Dinis mantenha relações pacíficas com os templários e que a eles recorra, em geral, para solicitar maiores benefícios para a Coroa.

Podemos enunciar alguns exemplos que demonstram este estado.

Logo em 1279, no início do seu reinado, D. Dinis confirma os privilégios e direitos da Ordem em Portugal, carta de que nos chega uma pública-forma notarial datada de $1291^{37}$. A 13 de Julho de 1285 , o soberano, considerando que "per aveença e per concordia partem-se muytas contendas, demandas e

${ }^{35}$ Ressalvando-se, contudo, uma excepção ditada por razões de parentesco: "Item Joam Perez Molaao de Souri disse com todolos artigoos e cousas como o dicto Duram Canelas salvo que disse que vira a o maestre Dom Joam Fernandez fazer ha seu sobrinho freyre que era galego." (Apêndice, doc. 1)

${ }^{36}$ TT - Gaveta VII, M 2, Doc. 4 e M 18, Doc. 2; Livro de Mestrados, fls. $143 v^{\circ}-150$. Apêndice, doc. 1.

${ }^{37}$ TT - Gaveta VII, M 10, Doc. 12; J. M. Valente, Op. cit., p. 243. 
desaveenças que som antre muytos homens que ham desvayrados corações e desvayrados prepoymentos e soi emtrar amor e paz antre elles per que veem a boom stado e a boa ciencia", assina uma carta de sentença pela qual determinava que a Ordem tivesse e mantivesse o monopólio dos lagares de azeite, na vila e termo de Tomar, o qual os vizinhos e o concelho contestavam, intentando fazer novos lagares e azenhas. Ao que lemos nesta carta régia, os templários exorbitavam claramente os seus direitos senhoriais sobre os nabantinos, sendo que estes não hesitaram em fazer ouvir o seu protesto junto do rei ${ }^{38}$.

Determinava, também, D. Dinis, que os rossios da vila fossem da Ordem e do Município, sem malícia, bem como que os moradores da vila pudessem ter mós em suas casas que "moesem o pam", impedindo-se, assim, que os cavaleiros as mandassem partir, como vinham fazendo, reconhecendo-se o direito dos moradores poderem haver as fornalhas em que cozessem o pão. Aos templários é reconhecido o direito a receberem o dízimo dos mostos em dinheiro, enquanto aos moradores se garantia a liberdade de fazerem os pombais e eirados que necessitassem ${ }^{39}$.

Por seu turno, em 31 de Maio de 1286, D. Dinis, "querendo fazer graça e mercee aa Ordem do Temple em meu reyno" confirma-lhes "seus boons privilegios e seus boos usos" $"$. A 10 de Julho desse mesmo ano, o monarca manda a todos os concelhos que a Ordem do Templo tinha no reino que todas as alçadas que viessem a ser efectuadas, o fossem "como ante husavades a filhar ata que vos eu mandar que todalas alçadas que as filhedes pera mim" ${ }^{41}$. No ano de 1297, foram concedidos aos freires, por graça e mercê, os padroados régios das igrejas de S. Mamede do Mogadouro e de Santa Maria de Penas Róias (Mogadouro), na diocese bracarense, com as suas capelas e ermidas e demais direitos ${ }^{42}$. Em Alcanizes, a 12 de Setembro deste ano, assinou-se o conhecido tratado de pazes e de delimitação de fronteiras entre D. Dinis e D. Fernando IV, de Castela e Leão. Fê-lo o monarca luso

${ }^{38} \mathrm{Vd}$. CONDE, Manuel Sílvio Alves - Tomar Medieval. O espaço e os homens. Cascais, Patrimonia, 1996, p. 48-49 et passim.

39 TT - Livro de Mestrados, fls. 24-25.

${ }^{40} \mathrm{TT}$ - Livro de Mestrados, fls. 23v ${ }^{\mathrm{o}}-24$.

${ }^{41}$ TT - Livro de Mestrados, fl. 25.

${ }^{42}$ TT - Livro de Mestrados, fls. 25-25v ; BRANDÃO, Fr. Francisco - Monarquia Lusitana, Parte Quinta, fl. 251. 
"com conselho e outorgamento" de muitos senhores e cortesãos, leigos ou eclesiásticos, afirmando-se expressamente entre eles os mestres das Ordens do Templo e de Avis ${ }^{43}$.

A D. Vasco Fernandes, "meestre da Ordem da Cavalaria do Tempre nos meus reynos e a essa Ordim outrossy", doou D. Dinis, com D. Isabel, por carta de 27 de Setembro de 1298, as casas que tinha no Sabugal, acrescentando o soberano que " esto lhis dou e outorgo per mha alma e per serviço que mi esse meestre fez" ${ }^{44}$. No ano de 1299, igualmente agradado para com o serviço que lhe prestara este mestre, D. Dinis entrega à Ordem, citamos, "todo o padroado e o dereito d'apresentar que eu ey e de dereyto devo a aver na mha egreja de Sancta Maria a Grande de Portalegre e nas capellas e nos logares que perteecem e som sojectos a dicta egreja ou perteecem e devem perteecer ou seer sojeytos a ela da qual egreja era o priol Gil Gonçalvez." ${ }^{45}$

Data de 17 de Setembro de 1304 a concessão real a "D. Vasco Fernandes Mestre da Ordem da Cavallaria do Temple nos nossos Regnos" da vila e do castelo de Penha Garcia e seu senhorio, "por muito serviço que vós nos fizestes e fazedes e porque entendemos que he nosso serviço e proveito de nossos reynos e do nosso senhorio." ${ }^{\prime 46}$ A 6 de Agosto de 1306, Fr. Gonçalo Fernandes, "tente o logo do Meestre nos meus reynos e Frey Lourenço Martiiz comendador do que a Ordem do Temple ha en Sanctarem e Frey Martim Affomso comendador do que a Ordem do Temple ha em Lixboa com outorgamento dos freyres" concordaram em ceder a D. Dinis a Lezíria dos Freires, que tinham no termo de Santarém, assim como o que tinham nos direitos da portagem de Coimbra e o padroado da igreja de Santiago de Trancoso "com toda sa freegresia e dizimas e com todas sas casas dessa egreja que estam amt'ela". Em troca, recebiam o padroado da igreja de

${ }^{43} \mathrm{TT}$ - Gaveta 18, M 9, № 13; publicado em As Gavetas da Torre do Tombo, Vol. IX, Lisboa, 1971, p. 500-504. Sobre as problemáticas pertinentes a este Tratado, vejam-se os diversos estudos compilados na obra $O$ Tratado de Alcanices e a importância histórica das terras de Riba Côa, Lisboa, Universidade Católica Editora, 1998.

${ }_{44} \mathrm{TT}$ - Livro de Mestrados, fls. 25vº-26; COSTA, Fr. Bernardo da Costa, - Histora da Militar Ordem..., Doc. LXXX, p. 298.

${ }^{45} \mathrm{TT}$ - Livro de Mestrados, fl. 26-26v ${ }^{\mathrm{o}}$.

${ }^{46}$ COSTA, Fr. Bernardo da - Historia da Militar Ordem..., Doc. LXXXIII, pp. 302-304. 
Alvaiázere, o senhorio de Vila de Rei e de Vila Ferreira, situada no termo daquela, mais o padroado da igreja deste dito lugar ${ }^{47}$.

Mas esta situação alterar-se-á depois de 1306. A boa-vontade de D. Dinis para com os freires templários manter-se-á, mas o rei não conseguirá evitar tomar algumas atitudes que, simultaneamente, aparentem proteger os seus cavaleiros, por um lado, e, por outro, que demonstrem não contrariar total e abertamente a política pontifícia neste campo. Sabemos que o soberano tomará para a Coroa os bens templários em Portugal, mas não há notícia de que tenham sido efectuadas prisões destes cavaleiros. Diplomaticamente, ou não, D. Dinis argumentará que os cavaleiros se foram do reino para se defender daquilo que os acusavam. Assim sendo, ausentes ou convenientemente esquecidos, mas não sem perigos e "medos", os templários portugueses sobreviverão a estes difíceis anos.

Entramos no período da perseguição e da iminente extinção da Ordem. Lembremos que fora em Salamanca que se reunira, em 1307, por determinação papal cometida à presidência do Arcebispo de Toledo, um concílio eclesiástico para averiguar das acusações contra os templários na Hispania. Castela assumia, nesse contexto, uma polaridade essencial na definição dos destinos da Ordem nesta província, os quais não deixariam de afectar a situação templária em Portugal.

Interessa ter presente que, com data de 4 de Dezembro de 1307, Eduardo II, de Inglaterra, dirigiu uma carta aos reis de Portugal, de Castela, da Sicília e de Aragão, expondo-lhes as suas reservas quanto à aceitação das acusações e rumores levantados em França contra os templários, nos quais o monarca britânico entrevia, não o recto zelo da justiça, mas antes o maligno espírito da cupidez e da inveja ${ }^{48}$. As relações entre Portugal e Inglaterra estavam, então, num momento particularmente positivo, como se demonstra pela assinatura, no ano de 1308, de um tratado de comércio entre os dois países. Em Portugal, contudo, os acontecimentos de França tiveram algum impacto. Ainda em 1307, por exemplo, D. Vasco Martins de Alvelos, bispo da Guarda, intentou contestar aos templários a posse de Idanha-a-

${ }^{47}$ TT - Livro de Mestrados, fls. 22-22v ${ }^{\circ}$.

${ }^{48}$ Citado por VALENTE, José M. - Soldiers and settlers: the knights Templar in Portugal..., cit., pp. 240-241. 
-Velha e de Salvaterra, que pretendia pertencerem à sua Sé, indicando terem sido obtidas pelos cavaleiros de forma fraudulenta ${ }^{49}$. Estando em Toulouse, a 3 de Janeiro de 1308, Clemente V dirige uma bula a D. Dinis pela qual the dá conta de estarem presos o Grão-Mestre e demais cavaleiros templários de França, pedindo-lhe que fizesse o mesmo em Portugal ${ }^{50}$. D. Dinis, contudo, mostrar-se-á muito prudente face a esta solicitação papal.

Sabemos que, antes de 4 de Fevereiro de 1308, já o Mestre e, pelo menos, os Comendadores de Pombal e de Soure se encontravam, oficialmente, fora de Portugal, para se defenderem, junto do papa, das acusações levantadas contra os templários. Informa o soberano, que, "o dicto meestre e comendadores se forom dos meus reynos pera cousas em que os aculpavam. E eu mandey filhar todalas cousas que o dicto moesteiro [sic; por mestre] [e] comendadores aviam nos meus reynos pera fazer delas ho que fosse dereito. (...) E eu porque achey que os nom podia julgar por revees de dereito porque se forom dos meus Reynos com medo daquelo em que os aculpavam e porque lhis eu tinha filhadas todalas cousas que aviam nos meus Reinos, nom nos podem julgar por revees de dereito mas tenho por bem que o feyto este em aquele estado em que ora está ata que o dicto Meestre e Comendadores pasem per seu dereito perdamte ho Papa sobre aquelo em que os aculpam", assim se sentindo obrigado a exercer o papel de guardião do património da Ordem ${ }^{51}$.

Naquela mesma data, D. Dinis, considerando não se poderem defender o mestre e os freires do Templo em Portugal, em certa matéria que opunha o Mosteiro de Santa Cruz de Coimbra aos comendadores de Pombal e de Soure, sobre algumas herdades em Carnide, no termo do Louriçal, manda que não sejam tidos por revéis, limitando-se a pôr as terras da contenda em sequestro ${ }^{52}$. Ainda em Agosto de 1308, no entanto, o Papa endereçará, sobre esta mesma matéria, cartas a vários bispos castelhanos e portugueses, nomeando-se o de Lisboa. Por bula de 12 desse mês, foram nomeados administradores apostólicos “omnium bonorum Ordinis

\footnotetext{
${ }^{49}$ Monarquia Lusitana, VI, pp. 112-116.

${ }^{50}$ Monarquia Lusitana, VI, p. 107.

${ }^{51} \mathrm{TT}$ - Santa Cruz de Coimbra, Livro 2, fls. 25-25v .

${ }^{52}$ Monarquia Lusitana, VI, pp. 106-107.
} 
Militie Templi Jerosolimitanis in regnis Castele" aos arcebispos de Toledo, de Compostela e aos bispos de Palencia e de Lisboa ${ }^{53}$.

Em 30 de Dezembro de 1308, Clemente V, uma vez mais, enviará a Jaime II de Aragão, a Fernando IV de Castela e a D. Dinis a conhecida bula Callidi serpentis vigil, na qual, lamentando que um ano depois das suas primeiras determinações sobre o assunto, enviadas aos mesmos monarcas, nas quais já então ordenava que fizessem prender os cavaleiros templários, não tivessem sido seguidas à risca as suas determinações, pelo que lhes ordenava agora, uma vez mais, que diligenciassem efectivamente no sentido de se concretizar a prisão que determinara e o procedimento inquisicional desses homens.

Entretanto, sabemos que, em Portugal, a 27 de Novembro de 1309, a Coroa se apropriava, contra o Mestre D. Vasco e a sua Ordem, das vilas de Soure, Pombal, Ega e Redinha, tendo julgado a causa o arcebispo de Braga, D. Martinho Pires de Oliveira, D. João Martins de Soalhães, bispo de Lisboa, o franciscano Fr. Estêvão, custódio olisiponense, e ainda Mestre João das Leis e Rui Nunes ${ }^{54}$. A 19 de Janeiro de 1310, levava-se a cabo uma inquirição sobre os direitos reais nas vilas de Idanha-a-Velha e de Salvaterra, que eram do Templo ${ }^{55}$. Dois anos depois, idêntica atitude conduzirá à integração nos bens da Coroa de Aguieira e de Moreira ${ }^{56}$.

Logo no dia 21 de Janeiro do dito ano de 1310, D. Fernando IV, rei de Castela de Leão, de Toledo, da Galiza, de Sevilha, de Córdova, de Murcia, de Jaen, do Algarve e Senhor de Molina, contando 25 anos de idade, proporá um pacto a D. Dinis, rei de Portugal, citamos: "por razon que todolos bienes que fueron de la Orden del Temple, assi villas, y castillos, y logares, e herdamientos quales quiere que la dicha Orden tenia en los mismos Reynos de Castilla, y de Leon, y ento nuestro senhorio, e otrosy los que avia en el reyno de Portugal y en todo vuestro senhorio fueron de los Reyes onde nos venimos, y de los otros homens que eran de los nuestros Reynos, que gelos diueron por herdade, e dar em que se mantuviessem la Cavallaria de la dicha Ordem del Templo a servicio de Dios y nuestro (...). Porque si la Orden ouviere a ser desfecha y el Papa quissesse fazer o ordenar alguna

\footnotetext{
${ }^{53}$ VALENTE, José M. - Op. cit., p. 247.

${ }^{54}$ BARROS, H. da Gama - História da Administração Pública..., II, p. 326.

${ }_{55}$ TT - Gaveta, XIII, M 4, Doc. 10; VALENTE, J. M. - Op. cit., p. 245.

${ }^{56}$ TT - Gaveta VII, M 4, Doc. 8; VALENTE, J. M. - Op. cit., p. 245.
} 
cosa de todolos dichos bienes, assi muebles como raizes para los querer sacar de nuestros senhorios, y de nuestra jurisdicion, que nós e vós que nos paremos e lo emparar e a lo defender contra todos aquellos que lo demandar quisieren. ${ }^{57}$

D. Dinis responderá positivamente a esta proposta de tratado, por carta datada de Frielas, a 14 de Abril desse mesmo ano de 1310. Nesta carta, contudo, o rei Lavrador fez anotar uma apostila pela qual se considera que, querendo D. Jaime II, de Aragão, aderir ao pacto, este se alargaria a ele nas condições definidas. Por esse tratado, os reis ibéricos concordavam, prevendo a eliminação da Cavalaria do Templo, em não deixar sair para o exterior qualquer bem pertencente aos templários nos respectivos reinos.

Naturalmente, seria irrealista pensar que conseguiriam impedir Filipe, o Belo, e, sobretudo, Clemente $\mathrm{V}$ de usarem a sua vantagem em matéria de jurisdição e de poder canónico. Mas uma coisa era a eliminação nominal e canónica, outra a tradução na prática dessa decisão que esbarraria, como vemos, com o exercício de um beneplácito régio luso-castelhano que se afirmava desde cedo como resolvido a não o implementar com eficácia neste espaço.

Esta estratégia diplomática surtiu efeitos, emergindo, como vimos, um bloco anglo-hispânico contrário à política franco-pontifícia que visava aniquilar a Ordem do Templo. Clemente V deve ter tido uma clara noção de que, mesmo que prosseguisse o desfazimento desta Ordem, essa decisão não afectaria de modo igual toda a Cristandade, muito em especial no seu flanco ibero-atlântico.

No dia 15 de Abril de 1310, em Tordesilhas, o arcebispo de Toledo, e os bispos de Palencia e de Lisboa, expediram um édito citando o preceptor-mor da Ordem do Templo na Hispania e todos os freires existentes nos reinos de Castela e de Leão, mandando-os comparecerem em Medina del Campo, a 27 desse mesmo mês, a fim de darem resposta às acusações de que eram alvo. Aqui, vários eclesiásticos portugueses, entre eles, como escrevemos, o bispo de Lisboa, mas também o reitor da igreja de Santa Maria da Arruda, o preceptor de Silves e um cónego desta diocese, testemunharam o exame

${ }^{57}$ Monarquia Lusitana, Vol. VI, Cap ${ }^{\circ}$ XXVI, pp. 109-110. 
e as conclusões que se revelaram improcedentes, mas remeteram ao Papa a decisão final ${ }^{58}$.

Pouco depois, em Outubro de 1310, em Salamanca, teria lugar novo concílio provincial sob a presidência do arcebispo de Santiago de Compostela. Neste participaram os bispos sufragâneos da arquidiocese compostelense, D. João Soalhães, bispo de Lisboa e D. Vasco de Alvelos, bispo da Guarda, este último, aliás, já nosso conhecido pela disputa que promovera contra os templários portugueses pela posse de Idanha-a-Velha e de Salvaterra. Reconheceu este Concílio a inocência dos cavaleiros, mas não ousou proferir sentença, deixando-a para o Sumo Pontífice ${ }^{59}$.

A 18 de Março de 1311, uma vez mais, Clemente V pressionaria Jaime II de Aragão para obter provas, mesmo que arrancadas à força, dos cavaleiros templários no seu reino, "ad habendum ab eis veritatis plenitudinem promptiorem tormentis et questionibus quibus et prout expedire noverint procurent exponere" ${ }^{90}$. Sabemos que o monarca aragonês, por carta de 17 de Agosto de 1311, dirigida a D. Fernando IV, de Castela, se associa à liga luso-castelhana estabelecida meses antes para defesa dos interesses nacionais de cada um destes reinos ${ }^{61}$.

A Ordem, entretanto, parece manter, em território português, personalidade jurídica ainda latente e activa no início de 1311. Data, efectivamente, de 12 de Janeiro deste ano, se não está incorrecta a informação, a doação aos cavaleiros templários portugueses, feita por Afonso Pires Ribeiro, de cinco casais, que deveriam integrar o património dos freires depois da morte do benfeitor. Para que tal sucedesse, em boa verdade, a Ordem não poderia estar formal nem canonicamente extinta.

Por sua vez, o Mestre D. Fr. Vasco Fernandes usufruiria, por esses dias, de alguma liberdade de movimentação. Sabemos que, no princípio do ano de 1312, este Mestre estava por terras castelhanas, aí tendo entregue, a título dito de empréstimo, 50000 torneses a D. Gonzalo Perez, mestre da Ordem de Alcântara, contra o recebimento do castelo e da vila de Valencia e até que o Papa lavrasse sentença final no caso que afectava a Ordem do Templo,

\footnotetext{
${ }^{58}$ BARROS, H. da Gama - História da Administração Pública..., II, p. 326-327.

${ }^{59}$ Monarquia Lusitana, VI, p. 108.

${ }^{60}$ Citado por VALENTE, J. M. - Op. cit., p. 250.

${ }^{61}$ BARROS, H. da Gama - História da Administração Pública ..., II, p. 328.
} 
"y despues que la sentencia fuere dada quier cobre la Orden del Temple lo suyo, quier non, que vos entreguasse á Valencia y vos que le entregasedes la vuestra casa de Vallellas, que habedes en Portugal." Tão elevada quantia em dinheiro, decerto saída do entesouramento templário em Portugal, foi prontamente cobiçada pelo rei castelhano D. Fernando IV, que dela se apropriou, tendo mandado prender a D. Vasco Fernandes ${ }^{62}$.

No Concílio de Vienne, cuja primeira sessão abriu a 16 de Outubro de 1311, estiveram presentes, em representação do episcopado de Portugal, D. Martinho, arcebispo de Braga, D. Fr. Estêvão, bispo do Porto e D. Rodrigo, bispo de Lamego. Para além destes clérigos, D. Dinis enviou alguns outros delegados seus. Conseguiram estes, como ainda os enviados das Coroas de Castela, Aragão e Maiorca, um estatuto especial para o património templário nos respectivos reinos. Em 22 de Março de 1312, Clemente V lavraria o decreto de abolição para sempre da Ordem do Templo.

Pela bula Ad providam, de 2 de Maio de 1312, decretava-se a integração dos bens do Templo na Ordem do Hospital de S. João de Jerusalém, exceptuando-se desta obrigatoriedade todos os bens dos templários nos reinos de Castela, Aragão, Portugal e Maiorca, uma vez que os respectivos reis exigiam incorporá-los e anexá-los às suas coroas. ${ }^{63}$ Uma segunda bula, lavrada a 6 de Maio desse ano, estipulava que, salvo algumas pessoas a serem julgadas pessoalmente pelo papa, todas as outras deveriam comparecer nos sínodos provinciais de cada país. Os que ficassem sem culpa, ou reconhecessem os crimes de que estavam acusados, teriam direito a receber pensão extraída dos rendimentos dos bens da Ordem. Os relapsos e fugitivos, contudo, seriam julgados com implacável severidade ${ }^{64}$.

Decretada a extinção, em 1312, relaxados à fogueira muitos dos cavaleiros franceses, ainda em 1314, será também nestes anos que se observará, em Portugal, um renovado interesse da política de D. Dinis acerca dos destinos do património da Ordem. O soberano constitui, então, João Pais de Soure e Afonso de Armes, seu guarda, inquiridores especiais para procederem a diligências sobre o estado dos bens materiais templários em Portugal.

\footnotetext{
${ }^{62}$ Citado por BARROS, H. da Gama-História da Administração Pública ..., II, p. 324-325.

${ }^{63}$ Monarquia Lusitana, VI, p. 192.

${ }^{64}$ BARROS, H. da Gama - História da Administração Pública ..., II, p. 329.
} 
Em Castelo Branco, secretariou um desses inquéritos João Martins de Montalvão, tabelião desta vila, a qual D. Dinis havia doado a sua irmã, a Infanta D. Branca, senhora das Huelgas de Burgos ${ }^{65}$.

Chegam-nos inquéritos promovidos pela Coroa, em Abril de 1314, em Soure, Castelo Branco, Montalvão e Nisa, pelos quais se interrogavam moradores destes concelhos, alguns deles, aliás, ex-freires professos - podemos citar, até, o exemplo de André Gonçalves de Pombal, que estivera em Acre, em 1291, no momento da queda desta fortaleza - acerca da actuação dos cavaleiros nessas terras e também no Reino ${ }^{66}$.

Sendo inquéritos controlados e lavrados pelos oficiais régios, seria de esperar que neles se encontrassem denúncias e argumentos que pusessem em causa, de algum modo, os objectivos fundacionais da própria Ordem, enquanto instituição criada para o serviço de Deus e os seus membros havidos por religiosos "espelho e exemplo" de todos os cristãos ${ }^{67}$. Ou, sobremodo, que dessas inquirições resultasse a denúncia de matéria incriminatória e desfavorável aos cavaleiros que justificasse o procedimento do braço real contra a Ordem. Mas o que lemos nas respectivas actas forenses, todavia, é, ao invés, bastante favorável ao legado templário. Resulta, numa sinopse de toda essa informação, que os freires templários, em Portugal, assumiam, naquele momento como no passado mais distante, uma identidade portuguesa e uma postura de fidelidade ao seu rei mais do que ao próprio mestre-geral de "além-mar".

Esta natureza nacional ou portuguesa dos freires templários no nosso País deve constituir, cremos, uma matéria de estudo mais alargada. Sem deixarem de ser templários, não punham de parte, também, a sua "linguagem". Naturalmente que esta dimensão psicológica e social da natureza nacional dos cavaleiros não terá sido sentida ou vivida sempre de forma igual nos séculos templários lusitanos.

${ }^{65}$ Monarquia Lusitana, VI, p. 192-193.

${ }^{66} \mathrm{TT}$ - Gaveta VII, Mํㅡㄹ 2, Doc. 4 e $\mathrm{M}^{\mathrm{o}}$ 18, Doc. 2; B) Leitura Nova: Livro de Mestrados, fls. $143 \mathrm{v}^{\mathrm{o}}-150$. Ref ${ }^{\mathrm{a}}$ : RIBEIRO, João Pedro Ribeiro, Memorias para a Historia das Inquirições dos primeiros reinados de Portugal, cit., p. 117.

${ }^{67}$ BARBER, M. C. - The social contexto f the Templars, cit., p. 27-28. 
Foi, contudo, esta fiel obediência e lealdade portuguesa dos freires do Templo que lhes garantiu a protecção e a continuidade, ainda que de acordo com cânones reformados, debaixo dos pendões da nova Ordem de Cristo. Para D. Dinis, quase poderemos dizer que os acontecimentos internacionais que levaram à agonia desta Ordem acabaram por vir ao encontro da sua atitude, sempre coerente, de procurar nacionalizar as Ordens Militares representadas em Portugal.

Após 1314, e sobremodo com a inauguração do pontificado de João XXII, em 1316, depois de cerca de dois anos de vacância da Santa Sé, D. Dinis encontrará os caminhos adequados ao seu intento de repor uma herança ainda que em termos actualizados em matéria de soberania e de jurisdição. O papa João XXII, em 1317, chegou a atribuir, em comenda, ao Cardeal Bertrando de Monte Favencio, o castelo e a vila de Tomar $^{68}$. Mas a firme contestação do soberano português acabou por levar ao encontro de outra solução ${ }^{69}$.

Segundo Fr. Francisco Brandão e D. Rodrigo da Cunha, o património da Ordem, arrestado pela Coroa, foi administrado pelo franciscano e bispo de Lisboa, em cujo bispado fora promovido por carta de Clemente V de 8 de Outubro de 1312, D. Fr. Estêvão (1313-1322). A ele, aliás, atribui o citado arcebispo olisiponense, a ideia, exposta ao rei, de se passar à instituição de uma nova Ordem Militar ${ }^{70}$. À cúria pontifícia foram enviados, por embaixadores de D. Dinis, o cavaleiro João Lourenço de Monsaraz e Pedro Pires, cónego da Sé de Coimbra, a fim de suplicarem a criação da nova ordem militar ${ }^{71}$. Desempenharam-se os delegados portugueses da sua missão com o maior êxito. A nova Milícia, designada dos Pobres Cavaleiros de Jesus Cristo, ficaria oficialmente domiciliada em Castro Marim e estaria sujeita à visitação espiritual do dom abade de Alcobaça que era, nesses anos, D. Martinho III (1318-1327)

${ }^{68}$ Monarquia Lusitana, VI, pp. 266-268.

${ }^{69}$ VITERBO, Fr. Joaquim de Santa Rosa de - Elucidário..., II, p. 602; Monarquia Lusitana, VI, p. 267.

${ }^{70}$ Monarquia Lusitana, VI, p. 193; Monumenta Henricina (Dir. A. Dias Dinis), Vol. I, Coimbra, 1960, pp. 101-102, notas 2 e 3; LOPES, Fernando Félix - Das actividades políticas e religiosas de D. Fr. Estêvão, bispo que foi do Porto e de Lisboa. Lusitania Sacra, 6 (1962-1963) 25-90.

${ }^{71}$ Que, a 16 de Março de 1319, já haviam obtido todos os resultados desejados pelo rei de Portugal. Vd. Monumenta Henricina, I, Doc. 65, pp. 122-123.

${ }^{72}$ Vd., entre outros, Monarquia Lusitana, VI, pp. 279-357. 
D. Dinis, a 4 de Junho de 1319, faz restituir à novel Ordem de Cristo as vilas, castelos e lugares de Soure, Pombal, Ega Redinha, situados na Estremadura tal qual esta província era então cartografada, e também as vilas e castelos de Idanha-a-Nova e Idanha-a-Velha, bem como de Salvaterra, Segura, Proença e Rosmaninhal, no bispado da Guarda, afirmando o soberano nesta carta "que a Ordem de Christo se tinha feito em Reformação da Ordem do Templo, que se desfez." As igrejas de Soure e de Pombal, que, pela extinção da Ordem do Templo, o rei reunira à Universidade, serão também entregues ao património canónico da Ordem de Cristo. ${ }^{73}$

A Ordem de Cristo, plausivelmente, terá visto reingressar, nos seus claustros, antigos cavaleiros templários. Nos estatutos desta, de 1321, aliás, fixou-se em 86 o número mínimo de freires a admitir, dos quais 71 deveriam ser cavaleiros ${ }^{74}$. Alguns dos seus antigos mestres encontravamse ainda sobrevivos nestes anos, como Fr. Lourenço Martins, vindo a ser sepultados no panteão dos mestres templários portugueses, o qual se fixara na bela igreja de Santa Maria do Olival, em Tomar. Na urbe nabantina, aliás, se enraizaria o núcleo de maior fecundidade na definição futura das marcas identitárias dos cavaleiros de Jesus Cristo. Sabemos, também e por exemplo, que D. Vasco Fernandes veio a falecer por 1323, depois de ter usufruído a comenda de Montalvão. Terá professado na Ordem de Cristo, muito embora haja notícia de certas diferenças que o terão oposto a ela, mormente a propósito da doação, que lhe fizera o rei, em 1304, de Penha Garcia ${ }^{75}$. Outros egressos templários poderão ter sido acolhidos por outras Ordens ${ }^{76}$. Mas essa é uma matéria a necessitar de ulterior investigação.

${ }^{73}$ VITERBO, Fr. Joaquim de Santa Rosa de - Elucidário..., II, p. 602.

${ }^{74}$ BARROS, H. da Gama - História da Administração Pública..., II, p. 333.

${ }^{75}$ VITERBO, Fr. Joaquim de Santa Rosa de - Elucidário..., II, p. 602; BARROS, H. da Gama - História da Administração Pública..., II, pp. 330-331.

${ }^{76}$ Como terá sucedido noutros reinos ibéricos. Vd. JOSSERAND, Philippe - Église et pouvoir..., cit., pp. 50-60; FERNANDES, Maria Cristina Ribeiro - A Ordem do Templo em Portugal..., pp. 224-228. Lembremos que, em 1324, os ex-templários portugueses, Afonso Esteves, Vicente Martins, Estevão Peres e Pero de Pena, integrando o Convento de Tomar, solicitam, aos Hospitaleiros da Coroa de Aragão, o pagamento das pensões que lhes eram devidas no contexto da extinção da Ordem do Templo, situação reiterada, em 1322, por Vicente Martins (MIRET i SANS, J. - Les Cases dels Templers i Hospitalers en Catalunya, Barcelona, 1910, pp. 395-396; SANS i TRAVÉ, J. M. - La fi dels templers catalans, Lleida, Pages editions, 2008, p. 393). 


\section{Apêndice}

\section{Doc. 1}

1314 ABRIL, 8, Soure - Inquirição em 25 artigos feita por João Pais de Soure acerca da natureza dos bens dos templários em Portugal, dependência destes face à Coroa, e das pessoas dos cavaleiros, do poder e da autoridade régia sobre os mesmos.

TT - Gaveta VII, $\mathrm{M}^{\mathrm{o}} 2$, Doc. 4 e $\mathrm{M}^{\mathrm{o}} 18$, Doc. 2

B) TT - Leitura Nova: Livro de Mestrados, fls. $143 \mathrm{v}^{\circ}-150$.

Ref ${ }^{\text {a }}$ : João Pedro Ribeiro, Memorias para a Historia das Inquirições dos primeiros reinados de Portugal, Lisboa, Impressão Regia, 1815, p. 117.

I A dicta Hordem de Christus. Outra de inquiriçam per que se mostra como os reis proveerom os templarios de castelos e vilas e lugares contanto que ouvesem somente os fruitos e remdas deles e os despemdesem em serviço del rey e do regnno e em guarda do dicto regnno e fezesem guerra a mouros e mais e $\mathrm{ct}^{\mathrm{a}}$.

Prime depositiones producte per Johanem Pelagii de Souri sub Era $M^{a}$ CCC $^{a}$ LII ${ }^{a}$, Colimbrie.

I Duram Canelas cavaleiro preguntado pelo primeiro artigoo disse // [Fl. 144] que ouvira sempre dizer e fora e era fama e creença na terra que o reyno de Portugal fora rejudo per o Conde Dom Anrrique assy come condado. E que o dicto Conde defendia a terra a mouros e fazia guerra contra eles.

T Item disse no segundo artigoo que ouvira dizer sempre e era fama e creença na terra e que el assy o creya que o dicto Conde avendo guerra com mouros que os freyres templareos veerom a el e pediron-lhy por mercee que o queriam servir e que lhis desse em que se mantevessem e de que podessem a mouros fazer guerra.

I Item disse no terceiro artigoo que ouvira dizer e era fama e creença e que assy o criia el por certo que esto meesmo pidirom os templareos al rey Dom Affonso seu filho e que assi o fezera o dicto rey.

I Item disse no quarto que ouvira sempre dizer que o dicto rey e os outros que depos el veerom proveerom aos templareos de muitos logares, vilas e castelos em esta maneira que os templareos recebesem as rendas dos 
logares e os fruitos e as rendas dos castelos que perteeciam aa casa do rey ${ }^{77}$ no reyno de Portugal e em guarda do reyno e pera fazer guerra a mouros e disse mais que era certo que os templareos serviam el rey contra mouros e contra tod'outro defendemento do seu reyno. E que em esto despendiam as rendas dos castelos e das vilas e logares que aviam no reyno de Portogal e que esto vira el per muitas vezes. E disse mais que sabia e era certo que nemhuãs remdas de vilas nen de castelo que os // [Col. B] dictos templareos ouvesem no reyno de Portugal que non ousariam emde levar nemhuã cousa ao maestre daalem mar senom per lecença del rey de Portugal. Ca diziam os reys de Portugal que queriam que as dictas remdas e averes se despendessem na sa terra de Portugal e a defendessem a mouros e que assi o faziam.

I Item disse no quimto artigoo que ouvira dizer de gram tempo aca que os dictos logares, vilas e castelos foram dados e cometidos em guarda aos templareos e que eles os lavrassem e melhorassem e que fielmente os gardassem pera serviço dos reys. E disse mais que assy vira usar e despender aos templareos as remdas em serviço dos reys e em defendimento da sa terra contra mouros e contra outros logares que fossem a defendimento do reyno de Portugal. E disse mais que vira per muitas vezes aos reys de Portugal filhar pera si as vilas e os castelos e os outros logares que os templareos aviam em Portugal e que metiam hy seus alcaydes e que recebiam as remdas de todo pera el rey. E que el rey fazya delles o que lhy prazia.

II Item disse no sexto artigoo que os logares, vilas e castelos que os dictos templareos aviam no reyno de Portugal que estavam todos por del rey e pera seu serviço e os templareos non os podiam emalhear em outra pessõa, mays el rey de Portugal cada que queria lhis filhava os logares que aviam e os dava a seus filhos e aaqueles que queria e que tinha por bem. E fazia el rey deles o que tinha por bem. // [Fl. 144v $\mathrm{v}^{\circ}$ E quando lhes el rey filhava vilas ou castelos os freyres lhy diziam: "Senhor voso he quamto nos avemos ca vos e vosos avoos no-lo destes, e em vos he de no-lo dardes ou de no-lo filhardes. Ca de vossa maao teemos nos todo e por vosso o teemos. $\mathrm{E}$ as rendas dos logares despendemo-las em voso serviço contra mouros e contra outros logares que sam a defendimento de vossa terra. Ca nossa he toda a propriedade".

\footnotetext{
${ }^{77} \mathrm{Na}$ margem esquerda da coluna: "Que os despendesem em serviço dos Reyx".
} 
E disse mais que era certo que os templareos steverom no Algarve pera defender a terra de Portugal contra mouros e que steverom por vezes em Chaves per mandado del rey pera defenderem a terra de Portugal e em outros muitos logares de fronteiras pera defenderem a terra de Portuga. E que el rey nom lhis dava nenhuã cousa pera despenderem senom as remdas das terras, vilas e castelos que os dictos templareos aviam no reyno de Portugal. E que assy o aviam os templareos com os reys d'uso e de custume. E que assy o serviam polas dictas remdas das vilas e do castelo e que assy o vira el sempre usar e fazer.

II Item disse no VII artigoo que os reys de Portugal reteverom em sy poder de revogar os dictos castelos e vilas que os dictos tempreiros aviam no reyno de Portugal e faziam os reys deles aquelo que tinham por bem.

I Item disse no octavo artigoo que ouvira dizer e era fama e creença certa que os freires templareos e os seus maestres que em Portugal viviam faziam menagem e juramento aos reys de Portugal // [Col. B] polas cousas que tinham no seu reyno com que o aviam de servir. E disse mays que se algun maestre viia pera seer maestre em Portugal que non emtraria no reyno de Portugal senon per mandado del rey de Portugal. E non seeria maestre senon per sa voontade. E outrossi disse que se o maestre queria hyr pera fora do reyno de Portugal que se non hya senon per lecença del rey de Portugal. E se se hya per lecença e avia de leixar alguem em seu logo non leyxava senon qual el rey mandava e tinha por bem.

TI Item disse no nono artigoo que ouvira dizer aos freyres templareos e a outras gentes que os templareos fezeram sempre menage ao rey de Portugal dos castelos e das vilas e logares que aviam em Portugal des sempre ata que a Ordem foy desfeita.

II Item disse no decimo artigoo que sempre os templareos foram teudos a servir fielmente polas dictas cousas os reys de Portugal com cavalos e com armas e com todolos seus em sas proprias despesas. E emquamto aos dictos reys prouguesse non lhis determinando tempo per quamto devessem servir. Mais serviriam el rey quamdo fosse sa vontade e tevesse por bem.

ๆ Item disse no onzeno artigoo que assy servirom sempre os templeiros el rey cada que lhy foy mester.

If Item disse no dozeno artigoo que os dictos templareos eram sempre teudo[s] servir os reys tambem em guerra quamdo fosse, come em outra 
maneira qualquer que aos dictos reys aprouguesse e que assi os vira el sempre // [Fl. 145] servir.

9 Item disse no trezeno artigoo que assy servirom sempre os templareos os reys de Portugal cada que lhis fazia mester.

I Item disse no catorzeno artigoo que os dictos templareos foram sempre teudos proveer aos dictos Reys de Portugal e a seus filhos e a sa familia e a toda sa gente avondadamente e honrradamente de cevada e de viandas e de todas outras cousas que ouvesse mester cada que passassem ou acaecessem pelos dictos castellos, villas e possissões que foram comemdas aos dictos templareos e que assy lho vira per muitas vezes dar.

II Item no quimzeno artigoo disse que assy foram sempre proveudos os dictos reys e seus filhos com sa familia e con toda sa gente assy como he de susodicto e que assy lhys vira sempre proveer.

II Item disse no $\mathrm{XVI}^{\circ}$ artigoo que non sabia se o maestre de Portugal devia receber aa dicta Ordem outro feyre salvo o de Portugal se non, mais pero disse que vira fazer muitos freires portugueeses e que nunca em Portugal vira fazer freyre que fosse castelãao nem doutra lenguagem senon de Portugal. E se em Portugal avia freyres de outra lemguagem vinham dalo fectos unde eram. E disse que freyre nemhuum non se faria em Portugal contra voontade de nosso senhor el rey e disse que non sabia doutra guisa.

78 Item disse no XVIII artigoo que quamdo o maestre queria fazer cabidoo pera dar as baylias e as teemças que o non fazia senon per mandado del rey. E que non sabia em como se davam as bailias e as // [Col. B] teenças ca non emtrava nemhuum leygo em seu cabidoo, mays pero disse que quando o cabidoo faziam que el rey mandava hum home boo ou dous de sa casa pera veer como se as bailias davam e pera os non leixar pelejar. E disse que se el rey queria que se desse baylia algua a alguem que se lhy dava e que sen nom fazia o cabidoo senon hu fosse vontade del rey.

${ }^{79}$ Item disse no XX artigoo que o mestre e os comendadores e os freires de Portugal eram teudos a nom sayrem nem se partirem do dicto reyno salvo se amte pedissem lecença aos reys e a guanhassem deles. E que esto vira el per muitas vezes. E que assy o viu usar e agardar sempre como dicto he.

\footnotetext{
${ }^{78}$ Saltou para o $18^{\circ}$ artigo.

${ }^{79}$ Saltou para o $20^{\circ}$ artigo.
} 
ๆ Item disse no XXI artigoo que vira aos reys de Portugal filhar os fruitos e as remdas dos beens que o Templlo avia no reyno de Portugal cada que el rey prazia. E recebia-os a sa mãao e fazia-os agardar pera seu profeito. Item disse que assy o vira usar e agardar per muitas vezes como dicto he.

II Item disse no XXII artigoo que os templareos e toda sa familia e toda sa gente fossem da jurisdiçom e do senhorio dos reys de Portugal tam bem em fecto de demanda civil como criminal que os Reys os podiam mui bem pear nos corpos e nos averes se fezesem por que. E faziam os reys em eles justiça cada que o mereciam. E nemhuum freire non podia fazer justiça em nemhuum malfeitor [e] em nemhuã terra que tevessem em Portugal, mas el rey essas justiças faziam hy dereyto e justiça.

TI Item disse no XXIII artigoo que // [Fl. 145v $\mathrm{v}^{\circ}$ ) ouvira sempre dizer e era certo que pelo poder que os reis em si gardarom e polos serviços que os dictos reys receberom dos dictos templareos per muytas vezes menagees, serviços, does e outras servidõoes muitas quaes prazia aos dictos reys. E disse mais que ouvira dizer per muitas vezes e era certo que quando ordinhavam dos bees pera fazer pobras e vilas e castelos que se novamente fezerom e outorgando as outras pessoas que vir[a] aos reys de Portugal receber a sa mão as vilas e castelos cada que lhis prazia e lhi fazia mester.

TI Item disse no XXIIII artigoo que os reis de Portugal conhecerom e julgarom sempre tambem dos fectos ceviis como criminaães movudos comtra os dictos templareos. E emqueriam ainda contra eles de seu officio das cousas criminaaes e faziam em eles justiça segundo seu merecimento.

T Item disse no $\mathrm{XXb}$ artigoo que das cousas de susodictas e de cada hua delas era voz e fama publica e creença no reyno de Portugal que assy passara e assy se usara sempre. E disse mays que sabia e era certo que os concelhos e os poboos das vilas e castelos e logares que foram cometudos aos templareos que non iriam em serviço dos templareos em hoste, nem em fossado, nem em castelos fazer senon per carta e per mandado del rey de Portugal cujos os concelhos eram e nos del rey se chamavam sempre e a el rey serviam ca aos freires non.

If Item disse que ouvira dizer e era certo per muitos que diziam que o virom que // [Col. B] Fernam Meendez homem poderoso trazia gram tempo o castelo e a vila de Souri por del Rey avendo ja hy os freires templareos a vila de Souri em que guarecessem. E que o dito Fernam Meendez fazia dar 
raçoes de comer aos freires e aa noyte sarrava os freyres dentro no castelo e aa manhaa vinha-lhis abrir. E que oyra dizer que fezera esto per gram tempo. E disse ainda que quando el rey ou seus filhos chegava aos castelos e aas vilas e aos outros logares que os tempreiros aviam que logo sende os freyres hyam e os deitavam fora e ficava el rey nos castelos e logares e fazia em eles come de seu.

If Item Domingos Paaez dicto Borrieyro morador em Souri disse en todolos artigoos e em todalas outras cousas assi como o dicto Duram Canelas.

I Item Martim da Redinha disse em todolos artigoos e em todalas outras cousas como o dicto Duram Canelas, salvo que no segundo artigo disse que non sabia se os templareos forom ao Conde Dom Amrrique que lhis desse em que se mantevessem. E outrossy disse no terceyro artigo que nom ouvira dizer nen sabia se era fama se os templareos pedirom em que se mantevessem al rey Dom Afonso filho do dicto Conde de que podessem a mouros fazer guerra. E outrossy disse que nunca vira em Portugal fazer freire doutra linguagem salvo que vira ao mestre Dom Joam Fernandez fazer freire huum seu sobrinho que era gallego mays em todalas outras cousas disse como o dicto Duram Canelas.

II Item Joam Perez Molaao de Souri disse em todolos // [Fl. 146] artigoos e cousas como o dicto Duram Canelas salvo que disse que vira ao maestre Dom Joam Fernandez fazer ha seu sobrinho freyre que era galego.

I Item Amdre Gonçalvez de Poombal disse em todolos artigoos e cousas como o dicto Duram Canelas. E disse mais que sabia e era certo e vira per muitas vezes que quamdo o cabidoo faziam os templareos que o faziam per mandado del rey e em outra guisa non. E que sempre el rey emviava ao cabidoo cada que o faziam huu seu crerigo pera receber as responsões pera serviço del rey. E que estavam per alvaraães do dicto crerigo del rey. E que el rey dava aos templareos pera despenderem o que queria e o al filhava pera sy. E se alguum serviço levavam ao mestre dalem mar era per lecença e per mandado del rey. E que se non fazia em outra guisa. E disse mays que ouvira dizer e vira aos freires em Portugal. E que ouvira outrossy dizer aos freyres na vila d'Acre que tinham el rey por baveca porque lhis dava nenhua cousa. Ca tod'aquelo em que eles guareciam em Portugal que todo era del rey de Portugal. E que se maravilhavam porque lhis leyxava nenhua cousa do seu levar aalem mar. E disse mays que el rey de Portugal recebia 
menagees dos maestres e dos freires dos castelos e das vilas e das fortalezas que lhy eles faziam. E quamdo os el rey queria tolher das fortelezas tolhialhas e metia hy outros alcaydes segraaes cada que queria. E disse mays que quamdo alguum infante nacia em Portugal que logo o maestre e os freyres lhy hyam beijar mãao e // [Col. B] recebe-lo por senhor e faziam menagem ao infante que depos morte de seu padre lh'emtregariam as vilas e os castelos e fortelezas e possissoes que aviam cometudo e em que guareciam em Portugal. E quamto hy aviam e em que guareciam todo era dos reys de Portugal. E que esto vira el per muitas vezes e disse mais que se alguns tesouros aviam os templareos sobrepostos de mays que as despesas que faziam que el rey de Portugal os filhava pera si.

ๆ Item Joam Steveez mercador de Poombal disse assy compridamente nos dictos artigoos e nas dictas cousas como o dicto Amdre Gonçalvez. E que fora bem quaremta anos per quarenta cabidoos e que sempre vira fazer o cabidoo per el rey. E que sempre hya hy huum seu crerigo ou seu messageiro que recebia por el rey as responsões.

- Item Miguel Eanes mercador em Poombal disse compridamente como os dictos Amdreu Gonçalvez e Joanne Stevez.

T Item Affomso Martiis Cerveira de Poombal disse compridamente em todolos artigoos e outras cousas como os dictos Amdre Gonçalvez e Joanne Stevez.

T Item Pay Meendez da Redinha disse em todalas cousas assy como Amdre Gonçalvez de Poombal, salvo que disse que non fora em Acri. E que non ouvira dizer aos freires como Amdre Gonçalvez que fora em Acre.

I Item Joam Louçaao de Souri disse em todalas cousas como o dicto Duram Canelas.

ๆ Item disse que ouvira dizer e que era certo per fama e per creença que Fernam Meendez que era alcayde por el rey em Souri seendo Souri ja dado em em [sic] co // [Fl. 146v $v^{\circ}$ menda aos freires que esse Fernam Meendez dava as rações aos freires e as cousas per que se mantinham e que os çarrava aa noyte no castelo e levava as chaves pera sa casa e que lhis abria aa manhaa e os deitava fora.

I Item disse que quando el rey chegava aas vilas e aos castelos e aas fortelezas dos templareos que os freires se sayam dos castelos e das vilas e el rey ficava nos castelos e nas fortalezas com sa gente. 
T Item disse que os concelhos e os moradores das vilas e dos castelos e das fortelezas dos templareos que non hiam em hoste nem em fossado, nem em anuduva com os freyres senom com el rey ou com seu mandado. Ca os concelhos del Rey eram e por seus se chamavam e el rey serviram ca non os freyres.

I Item disse que quando appelavam das vilas dos freires que hyam as appelações al rey.

I Item disse que quando o maestre vinha daalem mar fecto que non emtraria em Portugal senon prouguese al rey de o seer. E se lhy prouguesse de o seer que se non deterria esse maestre em nemhuum logar ata que non chegasse al rey e lhy beijasse mão e lhy fezesse vassalagem.

I Item disse que quamdo os reys de Portogal filhavam os castelos e as vilas e fortelezas aos templareos que ouvira dizer aos freyres: "El rey filhe o que quiser filhar e leixe o que quiser leyxar ca todo he seu e os nossos corpos e os nossos averes seus som e com todo avemos de servir ca de seus // [Col. B] padres e de seus avoos foy todo e non no-lo derom senon pera nos manteermos en el e pera servirmos el rey contra mouros e contra todas outras pessoas que quisessem dar guerra ao seu reyno."

TI Item disse que quamdo alguum infante nacia em Portugal que logo o mestre com os freyres lhy'am beyjar mãao e recebiam-no por senhor.

- Item disse que ouvira dizer e era fama e creença na terra que se os mestres tinham alguuns tesouros sobrepostos demais que as despesas que faziam que el rey os filhava pera sy.

II Item Lourenço Rijo de Souri disse compridamente em todolos artigoos e outras cousas come o dicto Amdre Gonçalvez, salvo que disse que non fora em Acre. $<$ E nom ouvio dezer aos freyres como Amdre Gonçalvez era em Acre.>

I Haec depositiones duxit Joannes Pelagii de Souri postrema vice cum venit Sanctarenam in mense Marcii sub Era quinquagessima secunda.

I Item disse Fernande Steveez tabelliom de Souri pelo primeiro artigoo que ouvira dezer per muytas vezes que o reyno de Portugal fora rejudo pelo conde Dom Anrrique assy como condado e que o dicto conde defendera a terra a mouros e fazia guerra contra eles. 
TI Item disse no segundo artigoo que ouvira dezer per muytas vezes que o dicto conde avendo guerra com mouros em quant'el viveu que os freyres tempreiros lhy veeram pedir per mercee que o queriam servir e que lhy dessem em que se mantevessem e de que podessem fazer guerra a mouros.

II Item disse pelo terceiro artigoo que ouvira dezer que morto al conde Dom Anrrique que ficou hum seu filho rey Dom Affomso e que // [Fl. 147] os templareos veerom a el e que lhy pedirom por mercee que lhy fezesse o que pedirom ao dicto seu padre.

I Item disse polo quarto artigoo que ouvira dezer que o dicto rey Dom Affomso e os outros reys que depos el veerom proveerom aos dictos templareos d'alguuns logares assy de vilas como de castellos eesta maneyra: que esses templares recebessem os fructos e remdas dos dictos logares, vilas e castellos do reyno de Portugal que perteeciam aa casa dos reys e que dependessem em serviço dos reys e guarda do reyno pera fazer guerra a mouros.

ๆ Item disse polo quimto artigoo que os logares e vilas e castellos foram dados e cometudos em guarda aos templareos e que eles os lavrassem e melhorassem e os guardassem pera serviço dos reys e que assy o ouvira dezer por muitas vezes e que sabia de certo que era pera sempre del rey.

I Item disse polo $\mathrm{VI}^{\mathrm{o}}$ artigoo que ouvira dezer que os dictos logares foram doados e cometudos aos dictos templareos so condiçom que elles non fezessem cousa per que os castellos e logares podessem seer alheados per nemhuuã razom em nemhuã outra pessoa.

II Item disse polo VII artigoo que ouvira dezer per muitas vezes que os reys de Portugal reteveram em sy poder de revogar os dictos castelos e vilas e logares que pelos dictos freyres fossem alheados.

II Item disse no VIII artigoo que ouvira per muitas vezes dezer que per razom das cousas de susodicto os dictos templareos eram teudos a fazer menagees e juramento e fieldade aos dictos // [Col. B] reys. E disse mays que sabia que ouvira dezer e era certo per alguuns que o ouvirom que Dom Paay Gomez Barreto seendo comendador de Castel Branco e teendo o castello que el rey Dom Affomso lhy filhou o dicto castello e o deu a Dom Fernamd'Afomso freyre. E Dom Fernamd'Afomso lhy fez menage com outros freyres que o non desse a outrem senon a el, ou a quem el mandasse. E que em outra guisa o non sabia. 
T Item disse polo noveno artigoo que era certo e que vira e padecera que os templareos eram teudos servir fielmente os reys polas cousas de susodictas com cavalos e com armas e com todolos seus em sas proprias despesas non lhis damdo el rey do seu nada. E que serviam aos reys emquanto aos reys prazia non determinando tempo emquamto ouveesem servir mays emquamto al rey prouguese e que esto vyo el de sempre.

I Item disse pelo decimo artigoo que era certo e vira per muytas vezes que os templareos eram teudos servyr os reys tambem em guerra como em outra maneyra qualquer que al rey prouguesse.

I Item disse que assy os vira sempre servir cada que al rey fazia mester.

II Item disse que des que se acordava aca que vira sempre e era certo que os templareos eram teudos proveer aos dictos reys e a seus filhos e a sãs gentes avondadamente de cevada e de viamdas e de todas outras cousas que ouvessem mester cada que passassem ou acaecessem pelos dictos castelos, vilas e possyssões que forom cometudas aos templareos. E diz que sempre assy vira usar e fazer. // [Fl. 147 $\left.\mathrm{v}^{\circ}\right]$

I Item disse que non sabia se o maestre avya de meter outros freyres salvo de Portugal se non.

I Item disse que o maestre que freyrava alguuns freyres por mandado del rey.

I Item disse que se o mestre tolhia alguã baylia a alguum comendador e the el rey mandava emtregar que lha entregavam.

II Item disse que o maestre e os comendadores e os freyres de Portugal eram teudos a nom sayrem nem se partirem do reyno de Portugal salvo per mandado e per lecença del rey. E disse que assy o vira sempre usar e custumar.

II Item disse que ouvira dizer que fora aveença e ordinança antre os reys e os tempreyros que todalas rendas dos beens que aviam os tempreyros em Portugal que estevesem em guarda pera serviço e proveyto dos reys do seu reyno e que asy se usou. E disse que era certo que nehuã cousa non se deviia tirar do reyno do aver dos templairos senom per mandado del rey. $\mathrm{Ca}$ el rey queria que estevese no seu reyno pera defendimento do reyno que que esto < que o > ouvira dezer a Dom Lourenço Martiinz que era maestre e a muytos freyres. 
TI Item disse que os templairos e toda sa família e toda sa gente eram de jurisdiçom e do senhorio dos reys também en demandas civiis com criminaães. E que os reys faziom justiça nos corpos dos freyres come nos de sa família se faziam por que.

ๆ Item disse que ouvira dizer que per muitos serviços e dõos que os reys receberam dos templeyros que os reys lhy leyxarom fazer pobras e vilas e castellos en que se mantevesem e com que servisem os reys e // [Col. B] con que defendessem o reyno de Portugal e que non fezesem delas senom o que el rey mandase.

If Item disse que vira e ouvira que o rey de Portogal conhocera e julgara tambem dos feytos civis come dos criminaaes movidos contra os tempreyros e que enqueria contra eles de seu officio das cousas criminaães e das outras e fazia a eles justiça segundo seu merecimento.

II Item disse que desto era fama e creença no reyno de Portugal e que assy se usara e costumara e que assy o vira el per muytas vezes.

TI Item disse que el rey Dom Affomso filhara os thesouros que o Tempre tiinha sobrepostos e fezera deles o que quisera.

ๆ Item disse que el rey Dom Afomso e el rey Dom Denis filharom per vezes ao Tempre os castelos e as vilas e as outras possisões que aviam no reyno de Portugal dizendo que eram suas e que metia hy alcaydes seus nos castelos alcaydes segrãaes e faziam-lhy menage dos castelos e logares come de seus logares proprios. E outrosy que metiam hy os reys seus porteiros que tiravam os dereytos todos da terra.

II Item disse que vira per vezes que os freyres serviom el Rey nas fronteyras e hu al rey prazia assy contra mouros come contra outros lugares que pera defendimento do reyno e que faziam tudo aquelo que al rey prazia ca o aviam de fazer de seu e per sas despesas per razom dos beens e logares que aviam em Portogal.

II Item disse que nenhuum maestre nom podia seer freyre em Portugal salvo se prazia al rey.

If Item disse que se o maestre daalem mar fezesse alguum maestre em Portugal que non entraria // [Fl. 148] em Portugal nem seeria dy maestre se al rey non prouguese.

I Item disse que ouvira dezer a freyres que tiinham el rey por baveca porque [nom] leyxava ao maestre nem outros freyres levar nenhuã cousa 
aalem mar nem a outro logar fora de sa terra ca quanto os freyres aviom em Portugal todo era dos reys e pera seu serviço e pera defendimento de sa terra e que em outra guisa non era dos freyres.

I Item disse que se el rey ouvese mester os concelhos das terras dos templeiros pera seu serviço que yriam com el de foro e de custume a quaesquer logares que a el rey prouguese.

II Item disse que ainda que o mestre e os freyres ouvesem mester os concelhos das sas terras pera seu serviço que non yriam com eles senon per mandado del rey ca os concelhos todos eram del rey e non serviam outrem senon el rey.

ๆ Item disse que se os joyzes das terras dos freyres julgavam ou davam sentenças que as apellações yam al rey come de seus concelhos.

I Item disse que os templeyros non faziam cabidos senom per mandado del rey e hu el queria e que el rey mandava hy seus de sa casa pera veer como faziam e pera põer das responsões em recado e que esto ouvira el assy dizer e dizia que asy era en del certo.

If Item Joam Dominguez dicto Boto que vive em Souri que foy freyre do Tempre disse em todo assy come Fernamd'Estevez.

qI Item Stevam Dominguez de Souri disse em todo come Fernamd'Esteveez. T Item Stevam Joannes tabeliom de Souri disse em todo como o dicto Fernamd'Estevez. ๆ Item Duram Dominguez de Souri disse assy em todo como o dicto Fernamd'Esteveez // [Col. B] \ Item Gomez Perez joiz de Souri disse assy em todo come o dicto Fernamd'Estevez. $\mid$ Item Pedro Cibraaez de Souri disse assy em todo como o dicto Fernamd'Estevez. ๆ Item Martim Cibraaez de Souri disse assy em todo come o dicto Fernamd'Estevez. ๆ Item Joam Louçãao de Souri disse assy em todo como o dicto Fernamd'Estevez. - Item Martim Solhoo de Souri disse assy em todo como o dicto Fernand'Estevez. ๆ Item Fernam Giraldez de Souri disse assy em todo come o dicto Fernamd'Estevez. ๆ Item Pedro Bissalho frade no Aljazede disse assy en todo como o dicto Fernamd'Estevez. $\uparrow$ Item Domingos Andre que chamam da Rua disse em todo assy como o dicto Fernand'Estevez. ๆ Pedro Giraldez de Souri disse compridamente en todo assy como o dicto Fernand'Estevez. T Martim Reymondo de Souri disse assy en todo compridamente como o dicto Fernand'Estevez. 9 Roy Martiiz de Souri disse assy em todo como o dicto Fernand'Estevez. ๆ Matheus Bufo da Ega disse assy em todo como o 
dicto Fernand'Estevez. \Joam Galego de Souri disse assy em todo como o dicto Fernamd'Estevez. ๆ Lourence Anes da Redinha disse assy em todo como o dicto Fernand'Estevez. I Paay Longo de Souri disse asy em todo como Fernamd'Estevez. ๆ Joam Dominguez Parayso de Souri disse assy em todo como Fernamd'Estevez. ๆ Joam Joannes carpenteyro de Souri disse assy en todo como Fernand'Estevez. ๆ Gil Eanes de Poombal disse assy como Fernand'Estevez. ๆ Joam Mouro de Souri disse assy como o dicto Fernamd'Estevez.

I Hos quidem de // [Fl. 148v'] positiones testium que seguntur duxit Arias Petri tribunus de Castel Branco.

ๆ Perdante mim Martim Anes tabelliom del Rey em Castel Branco Joanne Andre vio os artigoos em qual guisa em eles era conteudo. E disse polos artigoos antigos que os sabia per fama e per ouvida compridamente assy como em eles era conteudo.

E disse polos outros artigoos delo tempo del rey Dom Afonso aca que o sabia de certo assy como em eles era conteudo. E que vira filhar a baylia de Castel Branco ao Maeste Dom Beltram e da-la a Dom Payo. E que vira Pãay Garcia aministrador da baylia de Castel Branco e dar hy rações aos freyres per mandado del rey.

T Item Martim Porcariço da dicta vila de Castel Branco vistos os dictos artigoos como eelos era conteudo disse en todo como Johanne Andre.

- Item Martim Stevez cavaleyro da dicta vila ouvidos os dictos artigoos perdante my dicto tabeliom disse polos artigõos que eram antigos que os sabia de fama e d'ouvida come em eles he conteudo. E dos outros artigoos do tempo del rey Dom Afomso aca que os sabia de certo como em eles era conteudo.

TI Item Vaasco Fernandez morador en Nysa disse que sabia os artigoos antigos d'ouvida e de fama como em eles he conteudo e dos outros do tempo del Rey Dom Affonso aca que os sabia de certo e que o vira assy usar como em eles he comteudo.

T Item Roy Martiiz morador em Castel Branco disse que sabia todolos artigoos como em eles era comteudo salvo os antigos artigoos que os ouvio dizer a Dom Gonçalo Gonçalvez e a outros homes boons daquel tempo. 
II Item Martim Bicas disse que sabia bem os artigõs // [Col. B] salvo os antigos que os non sabia senom d'ouvida. E disse mays que ouvio dizer a Joam Soarez seendo procurador da Ordem que eles aviam todalas doaçoes pelos reys e que assy as aviam confirmadas per eles e que eles as gaanhavam servindo e defendendo a terra a mouros.

If Item Martim Dominguez da Rua Nova disse que sabia todolos artigoos como em eles he conteudo salvo os antigos que os sabia d'ouvida.

II Item Joam Vidal vistos todolos artigoos disse que sabia todolos do tempo de rey Dom Afomso aca e dos outros antigos que ouvira dizer a Dom Pãayo e a outros daquel tempo.

I Lõpo Perez disse que dos artigõos do tempo de rey Dom Afonso sabia deles a mõor parte. E dos outros artigoos que non sabia nada.

II Item Joam de Viseu disse que sabia os do tempo de rey Dom Affomso aca. E que dos amtigos que non sabia nada.

II Item Gil Fernandez Barreto vistos todolos artigoos disse que el era criado e mercee del rey e quando visse sa carta ou seu recado certo que el diria os que sabia < e que sabia $>$ mays ca o que era conteudo nos artigos. E que non avia homem no reyno que ende tanto soubesse que fosse a seu serviço.

II Item Paay Galego vistos os artigoos disse que sabia ende a moor parte dos dictos artigoos que eram do tempo del rey Dom Afomso.

I Item Pero Martiiz criado do Tempre vistos os artigoos disse que os sabia todos salvo os amtigos que sabia a mõor parte deles per ouvida e per fama.

I Item Lourenço Soarez que foy tabelliom vistos todolos artigoos disse que sabia todolos dictos artigoos do tempo de Rey Dom Afomso aca. E dos outros antigos disse que os sabia d'ouvida. E que el fora scrivam das rações que davam // [Fl. 149] naquel tempo aos freyres. E que estava hy, de maao del Rey, Dom Pedro Martiiz da Castinheyra que vira fazer as menagees aos freyres daquel tempo.

I E estas cousas de susodictas disserom as dictas pessoas perdante mim dicto tabelliom. E Ayras Pirez disse a mym da parte del rey que posese aqui o meu sinal por ser mays certo.

I Perdante mym Joam Martiiz tabelliom de Montalvam aa mercee da Infante Dona Branca filha do muy nobre rey Dom Afomso e Senhor das Olgas, Vicente Martiiz vio os artigõos em qual guisa em eles era 
conteudo. E disse polos artigõos antigos que os sabia per fama e per ouvida compridamente assy como [em] eles he conteudo. E disse polos outros artigõos delo tempo del rey Dom Affomso aca que o sabia de certo asy como em elles era conteudo.

I Item Joam Tiburço alcayde disse outra tal verdade como o dicto Vicente Martiiz. E disse mays que sabia Pãay Garcia estar em Montalvam de mãao del Rey. ๆ Item Dominguos da Guarda disse tal verdade como os de susodictos. ๆ Item Joam Prezado disse tal verdade como os de susodictos. ๆ Item Martim Canhestro disse tal verdade como Joam Prezado. ๆ Item Pãay Stevez disse tal verdade como os de susodictos. ๆ Item Joam Martiiz dicto tabelliom disse tal verdade como os de susodictos.

E desta fronta pediu Ayras Perez almoxarife del rey huum testemuyõ, feyto foy VI dias d 'Abril. Era de mill trezentos cinquoenta dous anos.

E eu Joam Martiiz tabelliom de Montalvom este tesemuyõ com mhã mãao propria escrevi. E meu signal em el pugi em testemuynho de verdade.

T Sabham todos que em presença de Martim Perez tabelliom de nosso senhor el rey em // [Col. B] Nysa a Nova, Ayras Perez almoxarife mostrou hum rool em que eram conteudos artigoos per que entendia provar o procurador del rey pelo qual mi pregumtou o dicto Ayras Perez do qual o meu acordo tal he:

Quamto he do tempo do conde Dom Anrrique e do tempo de seu filho rey Dom Affomso e da reynha Dona Tareyja e dos outros reys ata o tempo del rey Dom Affomso o vio assy contar a muytos homens boos assy como contam os artigoos. E do tempo del rey Dom Afonso e do tempo del rey Dom Denis que ora he seu filho compridamente todolos artigos que he como em eles he conteudo.

E sey e vi que Paay Garcia de cas del rey teve a sa mãao por el Rey a vila de Nysa a Velha e paravam hy oveençaaes por el rey. E davam raçõoes e governho aos freyres do Tempre e aas sas gentes. E eles eram manteudos dos beens da Ordem. E que vi a Dona Sancha Perez teer do Tempre o Rodam em sa vida.

q Item Duram Dominguez de Nisa a Nova disse em todo compridamente como < disse o dicto Estevam Pirez. ๆ Item Domingos Martinz que foi 
freire do Temple dise em todo compridamente como $>$ os de susodictos. II Item Pero Martiiz que foy tabelliom disse em todo compridamente como os artigoos assy como os de susodictos. II Item Affomso Martiiz que foy freyre do Tempre disse em todo compridamente assy como os dictos Stevam Perez e os oturos de susodictos. $\mid$ Item Domingos Perez que foy scryvam da compra disse em todo como os de susodictos. ๆ Item Joam Pereyro de Nysa a Nova que foy criado da Ordem do Tempre disse em todo compridamente como os de susodictos. ๆ Item Lopo Gonçalvez disse compridamente em todo como os de susodictos. - Item Stevam Martiiz vogado que foi criado de Dom Paay Gomez que foy maestre do Tempre disse em todo compridamente como todos // [FL. 149v $\mathrm{v}^{\circ}$ ] estes de susodictos. ๆ Item Domingos Paez da Roda disse compridamente em todo como cada huum dos sobredictos. ๆ Item Martim Cardido (?) disse em todo compridamente como todos os de susodictos.

I Item Gonçalo Fernandez que foy comendador de Nysa a Nova e d'Almoyrol e de Ryo Frio disse que ouvira dizer que a reynha Dona Tareyja deu aa Ordem do Tempre Souri e dali se probou Poombal e a Ega e a Redinha. E sey que por esto e por outras terras que ouvemos dos reys serviam e servi os reys com cavalos e com armas e com aver e com pam e com carne e com cevada e com outras muytas e muy nobres dõas e em guerras aa custa da Ordem cada que aos Reys prazia e vi-lhis reteer os castellos, vilas e outros logares e tiinha-os a sa maao com seus fruytos pera seu serviço e emtregavano-los quando era sa mercee. E a Ordem servia em sa parte quando os reys queriam e as gentes das vilas da Ordem a sa parte quamdo era mester de servirem assy.

Eu Stevam Perez tabelliom de susodicto esto com Ayras Perez almoxarife screvi per mha mãao propria. VIII dias d'Abril da Era de mil trezentos cincoenta dous anos.

If Estas testemuynhas trouve Vicente Afonso almoxarife de Thomar a Santarem.

I Estas som as pesõas per que se podem provar quamdo mester for estes artigõos que aqui som conteudos convem a saber:

Em Tomar primo: per Domingos Pãez Cousado que mora aa porta do Castelo. Martim Sesudo que mora na Rua de Maria Dona. Domingos Lopez 
que mora na Rua de Gil Vicente. Gil Stevez que mora na Corredoyra. Steve Anes tabeliom que mora no Castello. Martim Afomso // [Col. B] crerigo que mora na Rua de Gil Vicente. Martim Perez clerigo que mora na Rua de Sam Joanne. Domingos Requeyxo que mora em cima da Rua da Corredoyra. Joam Burges que mora na Corredoyra. Ayras Perez que mora na Corredoyra. Domingos Perez mesageyro que mora na Corredoyra. Matheus Martiiz que foy freire. Pero Martiiz scudeiro que mora na Çandoeyra. Joanne Meendez vigairo em Tomar. Martim Anes Calçaperra. Martim Anes Reganhado que mora na Corredoyra. Lourenço Anes que foy home de Joam Picom. Joam Fernandez que mora na Corredoyra. Stevam Ioannes filho de Joanne Stevez mercador. Domingos Martins Scudeyro que mora na Calçada. Stevam Lourenço dicto Menay crerigo que mora em Punhete. Domingos do Souto que mora na Rua de Garcia Rodriguez. Pero Cheo que mora na Varzea Pequena. Stevam Fernandez que mora na Varzea Pequena. Martim Peças que mora da Varzea Pequena. Joam Appariço que mora aa porta do Castello. Joam Stevez que foy vigairo de Tomar. Joam Gonçalvez tabeliom que mora na Rua de Sam Yoanne. Joam de Galiza que mora em Punhete.

I E leudos estes artigoos e cada huum specificadamente sobre sy amte cada huã das pessõas sobredictas apartadamente e em gram segredo achamos que os dictos artigoos se podem bem provar per eles salvo dous artigos.

O primeyro he em que diz que o mestre non poderia receber freyre na dicta Ordem salvo se fosse de Portugal.

E o outro em que diz que o mestre non podia fazer nemhuum freyre seu oveençal nem aministrador sem lecença dos reys.

E em todolos outros artigoos se concordavam de fama e de vista e d'ouvida salvo no primeyro que alguuns diziam que se nom acordavam nem ouviram dizer do conde Dom // [Fl. 150] Anrrique porque era de longuo tempo e destos eram muy poucos porque eram mancebos mays os mays destes que aqui som scritos s'acordam en todo. 